\title{
AMERICAN MUSLIMS: A NEW ISLAMIC DISCOURSE ON RELIGIOUS FREEDOM
}

\author{
A Thesis \\ submitted to the Faculty of \\ The School of Continuing Studies \\ and of \\ The Graduate School of Arts and Sciences \\ in partial fulfillment of the requirements for the \\ degree of Master of Arts \\ in Liberal Studies
}

By

John C. R. Musselman, B.A.

\author{
Georgetown University \\ Washington, D.C. \\ April 13, 2010
}




\title{
AMERICAN MUSLIMS: A NEW ISLAMIC DISCOURSE \\ ON RELIGIOUS FREEDOM
}

John C. R. Musselman, B.A.

Mentor: Chris Seiple, Ph.D.

\begin{abstract}
In 1998, the U.S. government made the promotion of religious freedom official policy. This policy has often been met with skepticism and hostility from foreign governments and publics. In the Muslim-majority world, it is commonly seen as an attempt to discredit traditional cultural norms and/or Islamic law, as covert support for American missionary activity, and/or as cultural imperialism. American Muslims could play a key role in changing this perception. To date, the American Muslim community has not become deeply invested in the movement for international religious freedom, but their notable absence has not been treated in any substantial length.

This thesis draws on the disciplines of public policy, political science, anthropology, and religious studies to explore this absence, in the process attempting to clarify how the immigrant Muslim American community understands religious freedom. It reviews the exegetical study of Islamic sources in relation to human rights and democracy by three leading American Muslim intellectuals—Abdulaziz Sachedina, M.A. Muqtedar Khan, and Khaled Abou El Fadl—and positions their ideas within the dual contexts of the movement for international religious freedom movement and the domestic political incorporation of the Muslim American community. After
\end{abstract}


comparing and contrasting their ideas, the thesis analyzes how their theory aligns with recent social, political, and economic developments in the broader Muslim-majority world.

The history of the movement and subsequent policy encapsulates the challenges that Muslim Americans face such as interfaith relations, government scrutiny, and political empowerment. These challenges have to date constrained Muslim American support for U.S. religious freedom policy. Yet while slow and even hesitant to broadly support U.S. international religious freedom policy, Muslim Americans have embraced the cause of civil and religious liberty in their own domestic context, which in turn has generated new conceptual frameworks fusing Islamic principles and American values. These fusions, which orient toward theology, philosophy, and jurisprudence, respectively, combine an appeal to reason with sacred Islamic sources, providing a potential touchstone for future generations of Muslims both in the U.S. and abroad in which to anchor the promotion of religious freedom in the Muslim-majority world. 
Rebecca Griffin, a true learner and teacher

Rest In Peace 


\section{ACKNOWLEDGEMENTS}

\section{SOLI DEO GLORIA}

I would like to acknowledge my family and friends, whose love, support, and counsel made the beginning, middle, and end of this thesis possible. I thank my parents, who were always glad to have a reader for a son. I thank my sisters and their families, who opened their homes for welcome breaks from work and school. I thank my friends, who all at some point endured an excuse about having to work on my thesis rather than live life together. I especially thank my best friend David Snouffer, who provided unfailing love, support, and counsel throughout the whole endeavor, and Stefan and Valerie Syski, who never lost an opportunity to affirm the value of my study. I also thank my friend and fellow student Laurence Mazzela, whose intellectual curiosity greatly enriched my graduate school experience. I thank my colleagues in the broad venture of improving Muslim-West relations, especially Tom Johnston for his patient pedagogy and generous help with government research, and my fellow bondworkers at the Institute for Global Engagement. Lastly, I thank with deep gratitude my advisor, Dr. Chris Seiple, for his deliberate stewardship of a teaching and mentoring opportunity in the midst of far weightier labors. 


\section{CONTENTS}

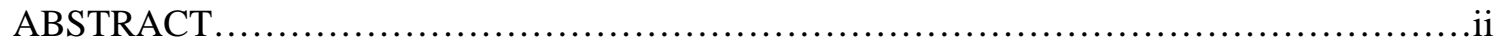

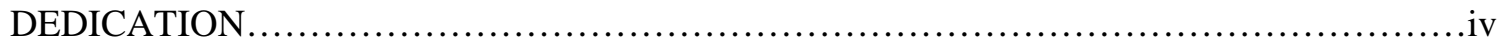

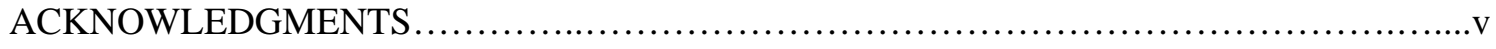

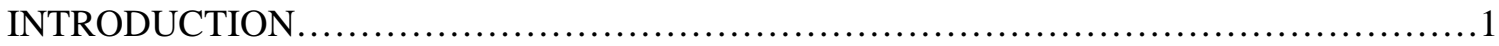

CHAPTER ONE: THE INTERNATIONAL RELIGIOUS FREEDOM CAMPAIGN.............4

CHAPTER TWO: THE POLITICAL INCORPORATION OF AMERICAN MUSLIMS.........30

CHAPTER THREE: AN AMERICAN ISLAMIC DISCOURSE $\ldots \ldots \ldots \ldots \ldots \ldots \ldots \ldots \ldots \ldots \ldots \ldots$

CHAPTER FOUR: IMPLICATIONS AND CONCLUSION............................... 84

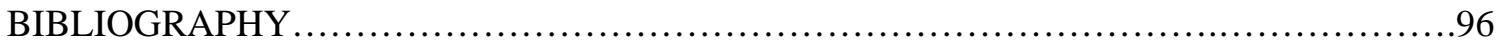




\section{INTRODUCTION}

International law affirms religious freedom as a fundamental human right. A host of international declarations, covenants, and agreements bears witness to nearly every country's agreement to uphold and protect the right of persons to choose, change and practice their religion. Yet religious persecution is sanctioned and in some cases mandated by governments around the world, including those of Muslim-majority countries.

In 1998, the U.S. government made the promotion of religious freedom official policy. This policy has often been met with skepticism and hostility from foreign governments and publics. In the Muslim-majority world, it is commonly seen as an attempt to discredit traditional cultural norms and/or Islamic law, as covert support for American missionary activity, and/or as cultural imperialism.

American Muslims could play a key role in changing this perception. To date, the American Muslim community has not become deeply invested in the movement for international religious freedom for a variety of reasons. At the same time, however, their experience of struggling for civil and religious liberties domestically has catalyzed a new discourse on religious freedom that fuses Islamic principles and American values, and which could prove helpful in laying an intellectual framework for Muslim-majority governments and publics to address the issue.

This thesis therefore attempts to "map" the rhetoric of American Muslims on international religious freedom by examining the theory of three prominent Muslim intellectuals living and writing in the United States. I first position their ideas within the dual contexts of the movement for international religious freedom movement and the political incorporation of the Muslim American community. After comparing and contrasting their ideas, I briefly analyze how 
their theory aligns (or doesn't) with recent social, political, and economic developments in the broader Muslim-majority world.

Two additional introductory comments are necessary. First, I use the terms "American Muslim” and "Muslim American” interchangeably. The usage in academic and popular parlance—by both Muslims and non-Muslims—-has shifted somewhat away from the former. This perhaps indicates complementary trends of increased pride in Islamic identity by Muslims and a growing awareness and appreciation among non-Muslims of their contributions to American civil society as a unique religious group. However, I insist on using both terms in order to remind my reader that the debate over civic and religious identity is very much alive, with each side in rich tension with the other-which is true for individuals and groups across the whole spectrum of the American religious landscape.

Second, when either term is used, it almost always refers exclusively to immigrant Muslims in America. The development of an indigenous Islam within the African-American community is a sociological drama that any student of Islam would do well to study. In many ways, African-American Muslims paved the way for immigrant Muslims in the social and political spheres within the United States. However, in the context of international religious freedom, the latter are more influential—in the short to mid-term at least—by virtue of their cultural heritage, family ties, and ongoing political and economic investments in their land of ancestry.

In 1921, Mohammad Karoub, an immigrant from Saudi Arabia, paid for the construction of a mosque in Detroit. Just two years later, following a theological disagreement among the congregation and subsequent decline in attendance, Karoub was obligated to dismantle the 
building. His words on the sequence of events brilliantly capture the promise that Muslims living out a principled pluralism in America have to advance the same abroad:

I have no word of censure for my people. If they differ with me as to the interpretation of the doctrine of Mohammed, that is their affair and their right. I believe fully in the liberty of conscience."

This is the challenge to Muslims and non-Muslims in America alike-that together we fully believe in the freedom of conscience.

1 “America’s Only Moslem Mosque to Go,” The Moslem World, Vol. 14, Num. 1 (January 1923): 82-83. 


\section{CHAPTER ONE}

\section{THE INTERNATIONAL RELIGIOUS FREEDOM CAMPAIGN}

This chapter recounts the public campaign for religious freedom in the late 1990s, the consequent passage of the International Religious Freedom Act, and the operation of the various government offices established by that act. This chapter is not an exhaustive treatment of either the pre- or post-legislation phases of the movement, but a summary of the movement's origins, characteristics, and effects. The chapter specifically draws out the story of the involvement of American Muslims in this movement (or lack thereof) and their subsequent interaction with the U.S. government agencies charged with promoting international religious freedom. This background is critical to understanding and assessing American Muslim rhetoric on religious freedom today.

The faith-based movement of the late 1990s marked a new chapter in human rights advocacy. It was not the first time that a coalition of American religious groups had come together to lobby the U.S. government to act internationally. The 1970s campaign to save Soviet Jewry anticipated many of the characteristics of the religious freedom movement twenty years later, and not least the decision to work through formal channels of state power. But the latter took place in a post-Cold War geo-political context, and it represented a broader and deeper chorus of domestic religious voices, made up of evangelicals, Catholics, and Jews, and other minority religious groups.

The inter-faith and intra-faith appeal carefully crafted by the coalition's leaders was an important part of the campaign. And to a large extent, the movement did reflect “unlikely alliances” among American religious groups, with the exception of American Muslims. Moreover, in the aftermath of the legislative campaign, neither the original constituency of the 
campaign nor the government offices charged with the execution of religious freedom policy has consistently or deeply engaged the American Muslim community commensurate with: a) the size of the American Muslim community as a domestic minority religious group; and, b) the great attention given to Islamic governments and Muslim-majority countries as persecutors. To date, then, apart from the public service of a few individuals on the United States Commission on International Religious Freedom, and scattered meetings between community representatives and U.S. foreign policy officials, American Muslims have not contributed significantly to the cause of international religious freedom in terms of debate or action.

The lack of engagement is attributable to three factors. First, the religious and political dynamics of the movement itself played a role by coloring perceptions of both domestic and international audiences. Initially framed as a campaign on behalf of persecuted Christians, the movement attracted a core constituency of conservative American evangelicals. This concentration of evangelical supporters, and the later addition of conservative Jewish groups, meant the importation of certain expressed views and attitudes about Islam—sometimes at the highest levels of coalition leadership—-that made the movement more difficult for American Muslims to embrace. In the long-term, however, the religious nature of the movement-and its subsequent theological rationale for religious freedom—-may be the key to realizing strong American Muslim support. This point will be explored further in Chapter Three.

Second, as Thomas Farr incisively narrates, an uninterested bureaucracy at the State Department, with little enthusiasm for religious engagement and even less for religious freedom, failed to sustain meaningful engagement with American Muslims on religious freedom over the past ten years. A few prescient officials such as Robert Seiple recognized the importance of engagement from the very beginning, but the trend has been towards inaction. Moreover, at the 
United States Commission on International Religious Freedom, the religious and denominational overtones of the movement have surfaced in allegations of anti-Muslim bias.

The third factor is the position of the American Muslim community itself. As will be explained in greater detail in Chapter Two, the posture of the community towards the international religious freedom campaign and subsequent U.S. policy is tied to its development as a social and political entity, especially in the context of the dramatic events of the last decade9/11, the Global War on Terror, and the U.S.-led invasions of Iraq and Afghanistan.

\section{Literature}

The two definitive works to date on the religious freedom movement come from insiders, Allan Hertzke and Thomas Farr. ${ }^{1}$ Hertkze, an academic well known for his study of religious lobbies, served as the movement's unofficial chronicler by invitation of some movement leaders. In 2004 he wrote Freeing God's Children, a detailed account of the faith-based human rights movement in the last two decades, which frames the history in a social science analysis. ${ }^{2}$ Hertzke explains major historical themes operative in and through the movement, identifies key figures, and evaluates the change brought by the movement as a whole to certain specific areas of U.S. foreign policy, including religious freedom. ${ }^{3}$

\footnotetext{
${ }^{1}$ Jeremy Gunn, former staffer in the Office of International Religious Freedom at the State Department, published an article in 2000 discussing the 1998 International Religious Freedom Act. Although it touches on criticisms of the legislation extant during the campaign, it is not a comprehensive history of the movement or campaign. See T. Jeremy Gunn, "A Preliminary Response to Criticisms of the International Religious Freedom Act of 1998," in Brigham Young University Law Review, 3 (2000): 841865.

${ }^{2}$ Alan Hertzke, Freeing God's Children: The Unlikely Alliance for Global Human Rights (Lanham, MD: Rowman \& Littlefield, 2004).

${ }^{3}$ In addition to religious freedom policy, Hertzke takes as case studies the campaign to end genocide in Sudan, and anti-trafficking laws.
} 
Thomas Farr served as the first director of the Office of International Religious Freedom (OIRF) at the State Department from 1999-2003. Subsequent to his retirement from State, he published World of Faith and Freedom, part manifesto and part insider story. ${ }^{4}$ His central thesis is that the U.S. government should take religion into clearer account in articulating and pursuing its foreign policy objectives. He argues that the promotion of international religious freedom represents a platform for the mainstreaming of religious considerations into U.S. foreign policy, and he describes how the Office of International Religious Freedom has (and hasn't) functioned to that end, from the perspective of the office itself.

In addition to these works, this chapter incorporates a collection of reflections on the International Religious Freedom Act ten years after its passage by key leaders and actors such as Nina Shea, Laura Bryant Hanford, and Robert Seiple, in the journal The Review of Faith \& International Affairs, and my personal interviews with former and current U.S. government officials involved in the execution of religious freedom policy. ${ }^{5}$

The Movement

In the early 1990s many Christian churches in the U.S. had became increasingly conscious of the persecution of Christians in other countries. A few American Christian authors had helped boost awareness through books specifically themed on Christians who were suffering abroad. ${ }^{6}$ In the mid-1990s two activists, Michael Horowitz and Nina Shea, took on the issue with

${ }^{4}$ Thomas Farr, World of Faith and Freedom (New York: OUP, 2008).

${ }^{5}$ The Review of Faith \& International Affairs, "Religious Freedom and Foreign Policy,” ed. Dennis Hoover and guest editor Thomas Farr, special issue, Vol. 6, No. 2 (Summer 2008).

${ }^{6}$ Hertzke, 125-127. The most widely sold books on the issue were Nina Shea, In the Lion's Den (Nashville, TN: Broadman \& Holman Publishers, 1997), and Paul Marshall, Their Blood Cries Out (Dallas: Word Pub., 1997). 
vigor and began recruiting evangelicals and others to press the U.S. government for a response. One early tool they used was the International Day of Prayer for the Persecuted Church, originally established by the World Evangelical Fellowship and marked each year with relatively little coverage, but which eventually became a major signboard for the campaign as a whole. ${ }^{7}$

In January 1996, Horowitz and Shea worked with the National Association of Evangelicals (NAE) and Freedom House to sponsor a conference on religious persecution in Washington, DC. The conference attracted 200 participants, including many prominent evangelical leaders such as Richard Cizik, Richard Land, Gary Bauer, and Ravi Zecharias. ${ }^{8}$ Two days later, the participants issued a "Statement of Conscience" that called for "universal religious liberty" and committed signatories "to do what is within our power to the end that the government of the United States will take appropriate action to combat the intolerable religious persecution now victimizing fellow believers and those of other faiths.” ${ }^{9}$ In many ways, this statement foreshadowed the legislation on international religious freedom that was to come. ${ }^{10}$

In February of the same year, Representative Chris Smith (R-NJ), Chair of the Subcommittee of International Human Rights of the House Committee on International Relations, held a hearing dedicated to persecution of Christians abroad. That summer, Congress passed a resolution requiring a report by the State Department on the persecution of Christians

\footnotetext{
${ }^{7}$ Hertzke, Freeing God's Children, 116.
}

${ }^{8}$ Nina Shea, "The Origins and Legacy of the Movement to Fight Religious Persecution,” in "Religious Freedom and Foreign Policy,” ed. Dennis Hoover and guest editor Thomas Farr, special issue, The Review of Faith \& International Affairs Vol. 6, No. 2 (Summer 2008): 25-31.

${ }^{9}$ Farr, 123.

${ }^{10}$ Hertzke, Freeing God's Children, 186-187. 
abroad, to include a catalog of U.S. policies in support of religious freedom. ${ }^{11}$ These events in the spring and summer of 1996 marked the beginning of the concerted campaign to make religious freedom a key objective of U.S. foreign policy.

Allan Hertzke argues that the faith-based movement for religious freedom wrote a new chapter in human rights advocacy. It signaled the burgeoning concern of American evangelicals for global issues, and the entrée of evangelicals onto the human rights stage, long a platform for liberal secularists. ${ }^{12}$ Although the initial impetus for evangelical involvement was a "parochial” concern for their fellow Christians, it soon evolved into a broader concern for "human dignity at large.”13 In this sense it represented "a kind of liminal movement in the politics of human rights.” But “American public opinion, rhetorical traditions, and national identity have long celebrated religious freedom.” ${ }^{14}$ So why did the IRF movement only come about in the last decade, and what prepared the ground for its course?

In some ways, the movement against religious persecution echoed the campaign in the 1970s to save Soviet Jewry. In that campaign, domestic religious groups successfully lobbied the U.S. government to take steps on the international stage in order to affect the situation of an oppressed religious group overseas. Through the Jackson-Vanik legislation, and the Helsinki Accords, the U.S. tied trade relations with the U.S.S.R. to the right of Soviet Jews to emigrate. The cooperation between American Jews and Christians, and the decision to work through the U.S.

\footnotetext{
${ }^{11}$ Shea, 26. The report, which focused on 78 countries, was issued in July 1997.

12 Thomas Farr and Dennis R. Hoover, The Future of U.S. International Religious Freedom Policy: Recommendations for the Obama Administration (Washington, DC: Georgetown University and The Institute for Global Engagement, 2009); Hertzke, 5.

${ }^{13}$ Hertzke, Freeing God's Children, 6.

${ }^{14}$ Farr and Hoover, 10.
} 
government, were repeated in the late 1990s by the faith-based movement to address religious persecution on an even broader scale. However, the latter campaign took place in a different geopolitical context, one in which religion had increasingly been addressed as a major global dynamic. ${ }^{15}$ Part of the new calculus was (and is) the transformation of global Christian demographics, particularly in the global south and east which now contain the majority of Christians worldwide. Historian Mark Noll in his 2009 book The New Shape of World Christianity puts the picture vividly:

- This past Sunday it is possible that more Christian believers attended church in China than in all of so-called "Christian Europe.” Yet in 1970 there were no legally functioning churches in all of China.

- This past Sunday more Anglicans attended church in each of Kenya, South Africa, Tanzania and Uganda than did Anglicans in Britain and Canada and Episcopalians in the United States combined-and the number of Anglicans in church in Nigeria was several times the number in those other African countries.

- This past Sunday more people attended the Yoido Full Gospel Church pastured by Yongi Cho in Seoul, Korea, than attended all the churches in significant American denominations like the Christian Reformed Church, the Evangelical Covenant Church or the Presbyterian Church in America. Six to eight times as many people attended this one church as the total that worshipped in the Canada's ten largest churches combined. ${ }^{16}$

Many of these Christians in the global south and east live under authoritarian regimes, which fear social movements as potential bases for political oppositions; thus, these rapidly swelling populations of Christians have triggered negative responses from their governments, leading to a reality of widespread persecution that did not exist before. ${ }^{17}$

Secondly, there has been a shift in the intellectual mood regarding faith. Fresh (and

${ }^{15}$ Hertzke, Freeing God's Children, 27.

${ }^{16}$ Mark A. Noll, The New Shape of World Christianity (Downers Grove, IL: Intervarsity Press, 2009): 9, 20.

${ }^{17}$ Hertzke, Freeing God's Children, 27, 36. 
probably overdue) attention has been given to the roles religious actors have played in facilitating conflict mediation, humanitarian aid, and faith-based initiatives. ${ }^{18} \mathrm{~A}$ faith-based activism for religious freedom or other issues thus finds a different reception than would have been expected just fifteen years ago. Finally, dense Christian networks in America, especially among evangelicals, and strong "grass-tops" leadership proved to be essential ingredients to the success of the IRF movement. ${ }^{19}$ The movement benefited tremendously from a cadre of charismatic, committed, and for the most part, respected voices such as Michael Horowitz, A.M.Rosenthal, Charles Colson, Richard John Neuhaus, and Frank Wolf. The relatively recent access to policymakers that evangelicals have enjoyed in the last decade probably also helped bring about tangible government action. ${ }^{20}$

The IRF movement started as a campaign against the persecution of Christians abroad. But despite the seemingly obvious common cause with their fellow religionists, Christians in the U.S. were not as united as might be expected. Hertzke keys in on the reasons for disunity, beginning with the simple fact that the "bewildering pluralism of Christians expressions" in the U.S. undermined a unified effort. Skepticism from mainline Protestants and an initially muted Catholic voice kept the face of the campaign an overwhelmingly evangelical one. But even within the evangelical camp there were several competing impulses: whether to focus on international religious freedom or domestic religious freedom; disagreement over methods (i.e., quiet diplomacy vs. tougher public sanctions); and theological debates over the nature and mission of the church. And black churches, despite being broadly aligned with the evangelical

\footnotetext{
${ }^{18}$ Ibid., 27.

${ }^{19}$ Ibid.

${ }^{20}$ See D. Michael Lindsay, Faith in the Halls of Power (New York: Oxford University Press, 2007) for an engaging analysis of evangelicals and political power.
} 
community, were reticent to join because of their concern that the IRF movement was a narrative of white evangelicalism (and therefore, in some cases, harmful to their relations with black mosques). ${ }^{21}$ Despite the disagreements raised by the movement, Hertzke concludes that it ultimately provided "a new modicum of ecumenicism” among American churches, and even among Christian and non-Christian communities in the U.S. ${ }^{22}$

Jewish participation was essential to this interfaith spirit. Perhaps the most important leader in the campaign, Michael Horowitz, was himself Jewish, and he felt keenly the need to broaden the movement base. Horowitz saw "how easily stereotyped a movement of evangelicals and Catholics could become” and "assiduously enlisted prominent Jewish backers” such as Abe Rosenthal, David Saperstein, Joseph Lieberman, Stacie Burdette, and Elliot Abrams. ${ }^{23}$ Horowitz also insisted on bringing other domestic religious groups to the table, such as Buddhists, Bahai's, and Coptics, in order that the movement "vividly reflect unlikely alliances." 24 These efforts did in fact succeed, giving the movement a intra- and interfaith appearance; the one notable absence was the American Muslim community. ${ }^{25}$

While the 1996 NAE statement referenced the persecution of Muslims around the world for their faith (by Muslims and non-Muslims), the movement's early stages were dominated by an

\footnotetext{
${ }^{21}$ Hertzke, Freeing God's Children, 79-95.

${ }^{22}$ Hertzke, Freeing God's Children, 114.

${ }^{23}$ Ibid., 152.

${ }^{24}$ Ibid., 169.

${ }^{25}$ Ibid., 197-198. Even the other groups were slow in coming. One Tibetan Buddhist, after sitting in on several movement planning sessions, remarked on the strange scarcity of references to non-Christians
} by movement members. 
almost exclusive focus on persecuted Christians. ${ }^{26}$ This was in part a strategic decision by Michael Horowitz and others later discarded for a more universal appeal. ${ }^{27}$ But it also reflected the orientation of that movement's majority evangelical Christian base, a constituency known for adverse attitudes toward the religion of Islam even before 9/11. Statements made in the 1980s by leaders from evangelical organizations such as World Vision, the Zwemer Institute, and the NAE cast Islam variously as evil, a threat to Christianity, and an affront to a perceived Christian heritage of America. ${ }^{28}$ "Theological suspicions" about Islam and its compatibility with religious freedom were even expressed by key leaders of the coalition, such as Horowitz, Father Richard Neuhaus, and Congressman Chris Smith, all of whom attracted attention for their negative public treatment of Islam in some instances. ${ }^{29}$ Horowitz’s first "salvo” on the issue was a 1997 editorial aimed at intolerance towards Christianity in the "Islamic Crescent," and he was subsequently criticized by some as holding a hidden agenda against militant Islam. Father Neuhaus wrote a May 1997 article in his influential conservative journal First Things in which he opined that Islamization was a very present danger to Europe. Finally, some criticized Congressman Smith’s hearings in the summer of 1996 as “Muslim bashing.”30

${ }^{26}$ Hertzke, Freeing God's Children, 24; Farr, 121-122.

${ }^{27}$ Shea, 26.

${ }^{28}$ Byron Haines, "Perspectives of the American Churches on Islam and the Muslim Community in North America" in The Muslims of America, ed. Yvonne Haddad (New York: OUP, 1991): 39-52.

${ }^{29}$ Farr, 124.

${ }^{30}$ Hertzke, Freeing God's Children, 71, 173, 175, and 187; and Mohammed Nimer, "Muslims in American Public Life,” in Muslims in the West, ed. Yvonne Haddad (New York: OUP, 2002): 182. 
Regardless of their actual views, the public perception of these leaders, and the coalition they represented, presented a challenge for American Muslims in terms of embracing the movement. For example, Ibrahim Hooper, Legislative Director for the Council for AmericanIslamic Relations (CAIR) in Washington, D.C., remarked: “[T]he co-sponsors of the International Religious Freedom Act are just a who's-who of Muslim bashers, those who want to convert somebody. They are not altruistic individuals wanting to protect co-religionists.” Faiz Rehman, editor of Pakistan-Link, concurred: "We're heading in a direction of saying Islam as a faith is what we have to fear.” Interestingly, even some Christian missionaries active in Islamic countries voiced concerns about anti-Muslim undertones, perhaps most notably Brother Andrew, a venerated figure in Western evangelical circles for smuggling bibles into Communist countries for forty years, and who had worked primarily in Muslim countries since the early 1990s: "I think we are creating an enemy image of the Muslims and making it worse, aggravating the problem." 31

As a result, American Muslims were not involved in the IRF movement proportionate to: a) their size as a domestic minority religious group with a stake in international religious freedom; and, b) the great attention given to Islamic countries as persecutors. Twice Hertzke enthusiastically lists different American religious groups_-“sympathetic minority voices”—as evidence of pluralistic participation in the cause, but neither $\mathrm{f}$ which mention American Muslims.

${ }^{31}$ Laurie Goodstein, “A Rising Movement Cites Persecution Facing Christians,” New York Times, November 9, 1998; Bob Harvey, “Saving Christians in the lions' den,” The Ottawa Citizen, December 21, 1998; and Mark O’Keefe, “Editorial: Persecution: widespread, complex,” The Oregonian, December 12, 1998. 
This is staggering, given that at the time Muslims in American greatly outnumbered some of the other groups listed, such as Buddhists (almost twice as many) and Bahai’s (five times as many). ${ }^{32}$

The spotlight was on Muslim countries from the beginning. For example, U.S. House Resolution 515, September 24, 1996 that condemned religious persecution mentioned three Muslim countries by name—Kuwait, Sudan, and Iran—and implicated others in "the Middle East.” Only China was mentioned more often. (The Senate version was more restrained, mentioning less countries by name). Hertzke himself obligingly explains the ubiquitous persecution of Christians in the "Islamic arc.” Moreover, early in his book he takes pains to acknowledge concerns of Muslim groups that IRF advocates targeted Muslim countries disproportionately and/or painted Islam in harsh light—but then proceeds to refute those concerns by arguing that: a) the movement addresses persecution against Muslim groups as well as Christians; b) the challenge is to authoritarianism in the Muslim world rather than Islam per se; c) moderate Muslim leaders do support the movement (often in private); and, d) ultimately IRF vitiates Islamic terrorism. The section reads as a defense of the movement more than anything else. ${ }^{33}$

The Legislation

In May 1997, Representative Frank Wolf (R-VA) and Senator Arlen Specter (R-PA) introduced the first legislation specifically dealing with religious freedom in the "Freedom From Religious Persecution Act.” The bill, which had originated with Michael Horowitz and been only slightly modified by Wolf's office, called for a tough public response by the United States to

\footnotetext{
${ }^{32}$ Hertzke, 32, 184. A third list that mentions other groups but not Muslims is mentioned in the context of Horowitz's framing of the campaign. These estimates are taken from the data presented on page 405 of Freeing God's Children, as extrapolated from World Christian Encyclopedia, ed. David Barrett, George Kurian, and Todd Johnson (New York: OUP, 2001).

${ }^{33}$ Hertzke, Freeing God's Children, 47-53, and 71.
} 
violations of religious freedom. ${ }^{34}$ It focused on only the most severe persecution, mandated automatic sanctions against violating nations that could only be waived by the President for national security reasons, and established a "Director of Religious Persecution Monitoring” in the White House with full authority to designate any religious community abroad as persecuted, and grant them refugee and asylum status. The guiding principle, Hertzke writes, was to "expose, shame, and...punish.”35

The Wolf-Specter bill, as it became known, attracted genuine bipartisan support with several prominent Democratic co-sponsors. ${ }^{36}$ But the heavy involvement of evangelicals meant that the bill would always carry a "crucial Republican element” in terms of political passage. Hertzke writes:

Republican staff members on the Hill admitted to me that there was a political need to "do something" for the conservative Christian community that helped the GOP seize control of the House after forty years of Democratic rule. ${ }^{37}$

Hertzke also notes the partisan ambitions of some leaders, notably Michael Horowitz, who spoke of using the issue to defeat Clinton in the November 1996 presidential elections. ${ }^{38}$

\footnotetext{
${ }^{34}$ Farr, 113; Laura Bryant Hanford, "The International Religious Freedom Act: Sources, Policy, Influence," in "Religious Freedom and Foreign Policy," ed. Dennis Hoover and guest editor Thomas Farr, special issue, The Review of Faith \& International Affairs Vol. 6, No. 2 (Summer 2008): 34.

${ }^{35}$ Hanford, “The International Religious Freedom Act: Sources, Policy, Influence,” 33-39, and Allen Hertzke, "International Religious Freedom Policy: Taking Stock," in "Religious Freedom and Foreign Policy," ed. Dennis Hoover and guest editor Thomas Farr, special issue, The Review of Faith \& International Affairs Vol. 6, No. 2 (Summer 2008): 19. CA).

${ }^{36}$ Hertzke, Freeing God's Children, 199. For example, Tony Hall (D-OH) and Nancy Pelosi (D-

${ }^{37}$ Ibid., 192, 199-200. The Congressional election referenced is that of 1994.

${ }^{38}$ Ibid., 175.
} 
While the bill attracted considerable support in the House, in large measure because of respect for Wolf's record on human rights issues, it faced intense opposition from a variety of actors. ${ }^{39}$ The Clinton administration publicly opposed it on the grounds that it would create a "hierarchy of human rights” that would distract the U.S. government from equally pressing issues. ${ }^{40}$ Big business, fearing that the bill would endanger contracts with and operations in offending nations, lobbied hard against the bill. ${ }^{41}$ Non-Christian religious groups, including some American Muslims, expressed concerns that the bill weighted persecution of Christians more heavily than others. ${ }^{42}$ And some mainline Protestant groups allied with liberal human rights organizations to suggest that the real problem was not persecution, but over-aggressive proselytization by foreign and indigenous Christians. ${ }^{43}$ Even among evangelicals, the bill sparked intense debate over methodology, with many favoring a more quiet, diplomatic approach over public denunciations and automatic sanctions. ${ }^{44}$

Despite these challenges, the Freedom From Religious Persecution Act was formally introduced to Congress on September 8, 1997. The lobbying campaign for the bill kicked off three months later in February 1998 with an event that included members of Congress and various religious leaders. On March 25, 1998, FFRPA was voted out of the House International

${ }^{39}$ Ibid., 201-209.

${ }^{40}$ Shea, 28. Secretary of State Madeleine Albright made the remark about hierarchy in November 1997 in a public address at Catholic University's Columbus School of Law. She later wrote about the importance of religious freedom in her book The Mighty and the Almighty (New York: HarperCollins, 2006).

${ }^{41}$ Hertzke, Freeing God's Children, 201-209.

${ }^{42}$ Hertzke, Freeing God's Children, 194.

${ }^{43}$ Shea, 28.

${ }^{44}$ Hertzke, “International Religious Freedom Policy,” 20. 
Relations Committee, and the next day, March 26, the Senate version of the bill (in reality a very different piece of legislation) was introduced in the Senate. On May 14, 1998, the FFRPA passed the House floor by a vote of 375-41.

In the Senate, however, Specter was unable to bring the legislation to the floor. Because it had stalled, key leaders of the IRF movement met with Senate policy staffers to discuss revisions to the bill. The meeting went poorly, with Horowitz in particular unwilling to countenance any criticism or changes. The bill appeared dead in the water, but in a surprising move, three Senate staffers dedicated to the issue of religious freedom—John Hanford, Laura Bryant, and William Inboden—-took it upon themselves to create an alternative version. ${ }^{45}$ This small cadre (later joined by Steve Moffit), working almost entirely independent of the WolfSpecter camp, drafted legislation that eventually became the International Religious Freedom Act.

Sponsored by Senators Don Nickles (R-OK) and Joseph Lieberman (D-CT), the bill focused on the broad promotion of religious rather than religious persecution per se. It established an Office of International Religious Freedom at the State Department, headed by an Ambassador-at-Large for Religious Freedom, and mandated an annual report by that office assessing religious freedom in every country except the U.S. While it retained the option to designate certain states a "Country of Particular Concern” (CPC) from the FFRPA, it did not mandate automatic sanctions, emphasizing instead escalating leverage through a menu of thirteen Presidential measures calibrated to the degree of offense. Finally, it created the U.S. Commission on International Religious Freedom as a Congressionally-funded but independent commission

\footnotetext{
${ }^{45}$ Hertzke, Freeing God's Children, 208-214.
} 
empowered to make non-binding recommendations on religious freedom policy to the President and Congress.

The Nickels-Lieberman bill directly challenged the Wolf-Specter bill on a number of points. The disparate personalities and the philosophies wrapped up in each bill generated very strong clashes; relations between the two camps quickly became heated, and at times, acrimonious. The Senate group believed the FFRPA to be “deeply flawed,” while the Horowitz group resented the Senate group’s “secret end-run” around their coalition. ${ }^{46}$

The International Religious Freedom Act, sponsored by Nickels and Lieberman, was introduced in the Senate in March 1998. But it was removed from the Senate docket in July for fear that it would not be passed and would thus become a "dead” bill. ${ }^{47}$ In September, with several former and active Republican senators agitating for IRFA's passage, members of the Wolf-Specter camp began focusing on the independent commission (to-be-USCIRF) as a way to realize their key objective of holding the State Department accountable for the implementation of new religious freedom policy. That month, prominent evangelical leaders signed a letter to Senator Nickels recommending a stronger commission. On October 8, IRFA passed the Senate by a vote of $98-0$. The next day, the very last day of the $105^{\text {th }}$ Congress, Congressman Wolf substituted IRFA in its entirety for FFRPA. Three weeks later, on October 27, President Clinton signed IRFA into law.

The Policy

\footnotetext{
${ }^{46}$ Ibid., 220-221. Compare the perspectives of Hanford and Shea of the other camp in "The International Religious Freedom Act” and "The Origins and Legacy of the Movement to Fight Religious Persecution,” respectively.

${ }^{47}$ Hertzke, Freeing God's Children, 222.
} 
IRFA established four major policy vehicles: 1) the Ambassador at Large for Religious Freedom; 2) the Office of International Religious Freedom (OIRF) at the State Department; 3) the State Department's Annual Report on Religious Freedom; and, 4) the United States Commission on International Religious Freedom (USCIRF), which was also to publish an annual report. Assessments of the separate and combined achievement of these vehicles in meeting the IRF movement's objectives have been mixed. There is agreement that the grander aspirations of the movement have not been achieved, but also admission that such lofty rhetorical goals as "undoing the bands of the yoke and letting the oppressed go free” are beyond the power of any one government, let alone one government agency. ${ }^{48}$ The weight of evaluation has thus fallen on the institutionalization of religious freedom within broader U.S. foreign policy vis-à-vis the four vehicles above.

In contravention of IRFA, the Ambassador has become subordinated to the Assistant Secretary for Democracy, Human Rights, and Labor (DRL) within State. This was in part due to a narrow interpretation of the IRFA mandate by State officials, and in part the strategic decision of the first two appointees, Robert Seiple and John Hanford, to accept the status quo and work quietly to build up their position and win the trust of other bureaus. ${ }^{49}$ During their tenures, despite being in theory the principal advisor to the President on religious freedom, they were regularly shut out of routine senior staff and senior policy meetings. ${ }^{50}$ This attitude seemed reflected at the highest levels—George W. Bush did not even appoint an Ambassador until 18 months after taking office, and as of this writing, the Obama administration has kept the post

\footnotetext{
${ }^{48}$ Hertzke, “International Religious Freedom Policy: Taking Stock,” 21; Shea, 30.

${ }^{49}$ Farr, $140-144$ and 194-195.

${ }^{50}$ Farr and Hoover, 19.
} 
vacant for 14 months. Nevertheless, both Seiple and Hanford utilized many of their granted powers and set important precedent for their successors by negotiating directly with foreign governments, encouraging those governments to reform certain laws governing religion, engaging foreign and domestic constituencies, and using their authority and resources at State to directly affect the release of individuals detained or tortured for their faith. ${ }^{51}$

Ambassador Seiple also established an important precedent in his efforts to engage the American Muslim community. Three years before 9/11, Seiple created a regular venue at the State Department where Muslims and American foreign policy officials could meet. ${ }^{52}$ Initially called the "Islamic Roundtable," its title was changed to the more domestic “American Muslim Roundtable” by Farr, who continued the forum after Seiple stepped down in 2000 to found the Institute for Global Engagement, and before the position had been filled by the incoming Bush administration. Farr brought in diverse views, including converts to Islam, Sunnis, Shiites, and even self-professed secularist Muslims. Farr extended the series to Buddhists and Hindus, with plans to bring in Jewish and Orthodox Christian participants, among others, but the forum, which had never generated much interest at State outside OIRF, was quickly discontinued by Seiple's successor, Ambassador John Hanford. ${ }^{53}$

The Office of International Religious Freedom has suffered many of the same woes as the Ambassador position. Within the larger foreign policy bureaucracy, and even within the human rights bureau, it has been, in Farr's wry phrase, “quarantined.” ${ }^{54}$ In 2003, just five years

\footnotetext{
${ }^{51}$ Farr 159 and 209; Hanford, 37.

${ }^{52}$ Farr, 159.

${ }^{53}$ Farr, 165.

${ }^{54}$ Hertzke, “International Religious Freedom Policy: Taking Stock,” 23.
} 
after the passage of IRFA, the State Department's Inspector General concluded that the "current structure” which relegated OIRF within DRL was “unworkable.”55 This isolation of OIRF reflects the failure (until now) of the IRF movement to mainstream religious freedom in U.S. foreign policy as a whole. Yet the office has definitely increased in size and stature over the past 10 years, growing from “a vacuum cleaner and a contract secretary” to a staff of 25.

The office meets with foreign government officials, as well as religious and human rights groups in the U.S. and abroad; testifies before Congress on issues of international religious freedom; sponsors reconciliation programs where disputes divide groups along religious lines; and conducts outreach to American religious communities, including American Muslims. ${ }^{56}$ OIRF has also become a resource for U.S. diplomats and officials, such as the Special Representative to the Organization of the Islamic Conference, requiring special knowledge of religious developments in their post country or policy forum. ${ }^{57}$ OIRF staff recently (2009) developed and hosted an agency wide forum dedicated to the discussion of religion and international affairs. However, OIRF's most important mission by far is producing the Annual Report on International Religious Freedom.

The Annual Report describes the status of religious freedom in each of the 195 countries throughout the world (not including the United States). Reporting starts with embassy staff; the material is sent to Washington where OIRF compiles the material, conducts further research, and prepares the manuscript. The report classifies violations of religious freedom according to a five-

\footnotetext{
${ }^{55}$ Farr and Hoover, 19-20.

${ }^{56}$ U.S. Department of State, Office of International Religious Freedom, Fact Sheet, available at http://www.state.gov/g/drl/irf/index.htm.

${ }^{57}$ Author interviews with OIRF officials, June 2009.
} 
point typology, which has successfully transferred to the advocacy arena and is used by activists. ${ }^{58}$ In addition, the report discusses positive developments toward greater religious freedom, if any, in each country. Generally well-considered, and to some even the "gold standard” of international religious freedom reporting, the Annual Report "convey[s] solidarity to embattled victims around the world" but also provides a "springboard" for negotiations with foreign governments. ${ }^{59}$ The reports have impacted the U.S. diplomatic mindset by encouraging embassy personnel to take more careful watch of the religious landscape in their posting by developing "intimate knowledge” of local religious actors and communities. ${ }^{60}$ According to Farr, the report "has done more than anything else to change secular U.S. diplomatic culture."61

However, the Report has generated concerns that the U.S. does not monitor itself, especially in the context of questionable treatment of American Muslims after 9/11. Likewise, the onset of the Global War on Terror (GWOT) under the George W. Bush administration led some to question whether reporting on allies would become biased, i.e., the State Department would not report problems occurring in countries that were aiding U.S. counter-terrorism efforts, but this concern has to proven to be somewhat inflated by the steady reporting on Saudi Arabia, Iraq, and Afghanistan. ${ }^{62}$

${ }^{58}$ The five categories, in descending order, are: persecution, repression, harassment, limitations, discrimination. For an example of their use outside of State, see H. Knox Thames, Chris Seiple, and Amy Rowe, International Religious Freedom Advocacy (Waco, TX: Baylor University Press, 2009).

${ }^{59}$ Bryant, 37.

${ }^{60}$ Hertzke, “International Religious Freedom Policy: Taking Stock,” 21.

${ }^{61}$ Farr, 114. In 2009, the State Department began publishing the Report in 148 additional languages to increase international readership.

62 Jane Dammen McAuliffe, “Monitoring for Religious Freedom: A New International Mandate,” Religious Liberty: A Theme for Christian-Muslim Dialogue, The Commission for Religious Relations with 23 
The United States Commission on International Religious Freedom also generates an annual report. Originally proposed in the Nickels-Lieberman bill, the idea of the Commission, as an independent body empowered to do its own fact-finding and hold State accountable, became dear to the Wolf-Specter camp, which in its own legislation had attempted to bypass a distrusted foreign policy bureaucracy. Through various stages of compromise, USCIRF took shape in IRFA as an independent, bipartisan, governmental entity charged with: 1) fact finding on global religious freedom and issuing its own annual report; and, 2) making non-binding policy recommendations on issues such as the designation of CPC status. To this end, the Commission is authorized to meet with foreign governments, religious communities, and private groups, and make public hearings and statements. However, the Commission has no formal influence outside "the force of its own persuasion."63

Like the other organs of IRFA, USCIRF has received mixed reviews for its work over the last eleven years. While it has received praise by some for the bipartisan tenor and multi-faith spirit with which it operates, it has been criticized for operating with a misdirected focus and having little real impact in the policy arena. ${ }^{64}$ Predictably, some officials in OIRF have come to view the Commission as repetitious, and even unhelpful to the cause of "quiet diplomacy.” Yet others (outside State) laud the Commission's efforts to make sure the State Department does not “fudge” its reporting; and while the Commission’s relatively more blunt reporting can create

Muslims, (Vatican City: The Pontifical Council for Inter-religious Dialogue, 2006): 180-181. In contrast to the United States, Europe has strong self-reporting.

${ }^{63}$ Tad Stahnke, “A Paradox of Independence: The U.S. Commission on International Religious Freedom," in "Religious Freedom and Foreign Policy," ed. Dennis Hoover and guest editor Thomas Farr, special issue, The Review of Faith \& International Affairs Vol. 6, No. 2 (Summer 2008): 48.

${ }^{64}$ Ibid. 
awkward moments for U.S. diplomats, especially when the Commission is taken by foreign governments to be an official organ of U.S. religious freedom policy, it can also create an advantageous "good cop/bad cop” dynamic for the same diplomats. ${ }^{65}$ Perhaps most importantly, the Commission itself can serve as a model of American religious pluralism by virtue of its multi-faith make-up. ${ }^{66}$ Commission seats have been held by accomplished individuals from the evangelical, Catholic, Jewish, Muslim, Bahai, and Hindu communities in the U.S.

American Muslims have been represented on the Commission since its inception in 1999, always holding at least one seat, and two seats from 2001-2003. ${ }^{67}$ Democratic and Republican administrations, and the Senate have appointed American Muslims. This arrangement has never been mandated by Congressional statute, however, and continues solely at the discretion of the party and branch whose turn it is to fill Commission seats. ${ }^{68}$ As Hertzke notes, this norm "plays a modest role in fostering debate within the Muslim community about the status of religious freedom in Muslim countries.”69

But the workings of the Commission also reveal persistent perceptions of domestic antiMuslim bias. One of the first Muslim appointees, Dr. Laila al-Marayati of the Muslim Women League, was opposed by major Jewish groups on the grounds that she was “weak on terrorism.”70

${ }^{65}$ Hertzke, "International Religious Freedom Policy,” 20; Shea, 29. Shea characterized this as “political vetting.” See also A.M. Rosenthal, “Clinton’s Fudge Factory,” New York Times, May 1, 1998.

${ }^{66}$ Hertzke, Freeing God's Children, 306.

${ }^{67}$ Leila Al-Marayati, 1999-2001; Leila Naya Sada, 2001-2003; Shirin Tahir-Kheli, 2001-2003; Khaled Abou El Fadl, 2003-2007; and, Imam Talal Eid, 2007-present.

${ }^{68}$ Interview with Commission staff, February 2010.

${ }^{69}$ Hertzke, Freeing God's Children, 310.

${ }^{70}$ Mohamed Nimer, "Muslims in American Public Life," in Muslims in the West, ed. Yvonne Haddad (New York: OUP, 2002): 182. This was the same charge that Jewish groups used to force Dr. Al25 
In February 2010, the Washington Post reported that a former policy analyst had filed a complaint with the Equal Employment Opportunity Commission alleging that her contract was canceled because of her Muslim faith and previous work for an American Muslim advocacy group. Commenting on the case, Khaled Abou El Fadl, an Egyptian-American and eminent Muslim authority on Sharia, democracy, and human rights (profiled in Chapter Three) who served as a Commissioner from 2003-2007, described the Commission environment as "stifling” and implied the presence of mutually reinforcing pro-Christian and anti-Muslim biases: "It was pretty clear who the bad guys were."${ }^{, 71}$

Finally, the religious freedom movement has also been indirectly institutionalized through the non-governmental sector, where a number of think tanks, advocacy organizations, and foundations have taken up the cause. ${ }^{72}$ In the late 1980s, only two or three NGOs in Washington, DC focused on religious freedom issues. ${ }^{73}$ Now the ranks include, among others, Freedom House, the Center for Religious Freedom at the Hudson Institute, the Ethics and Public Policy Center, the Institute for Global Engagement, the Institute on Religion and Democracy, the Pew Forum, the Fieldstead Foundation, the Maclellan Foundation, the Templeton Foundation, and the Luce Foundation. These organizations may be the key to sustaining the popular support for religious freedom that many movement leaders see as essential for future gains. ${ }^{74}$ At present,

Marayati's husband, Salam Al-Marayati, from his appointment to the National Commission on Terrorism in 1999.

\footnotetext{
${ }^{71}$ Michelle Boorstein, "Agency that monitors religious freedom abroad accused of bias," Washington Post, February 17, 2010, A11.

${ }^{72}$ Hertzke, “International Religious Freedom Policy: Taking Stock,” 22.

${ }^{73}$ Hanford, 33.

${ }^{74}$ Hertzke, "International Religious Freedom Policy: Taking Stock,” 22-23; Shea, 31.
} 
there are no American Muslim organizations taking on international religious freedom per se, although several are implicitly addressing them in their approach to broader issues such as democracy and human rights in the Muslim majority world. ${ }^{75}$ The link between democracy, religious freedom, and Islamic discourse will be explored further in Chapter Three.

The implementation of IRFA began the institutionalization of religious freedom in the State Department, the traditional center of U.S. foreign policy. Both the Clinton and Bush administrations specifically articulated the importance of religious freedom in their National Security Strategy reviews, “the most magisterial statement of [the] White House’s foreign policy doctrines and policies”76; both presidents approved the designation of a key trading partner or ally as a $\mathrm{CPC}^{77}$; hundreds and maybe thousands harassed, imprisoned or tortured for their convictions have been freed through unrelenting OIRF case work ${ }^{78}$; foreign governments protest their treatment in the Annual Reports; and official dialogue with Vietnam, once a CPC, has led to sweeping reforms in that country's policies. ${ }^{79}$ However, policy has not caught up to the emerging consensus in the field of religious freedom promotion that a) religious freedom is inherently linked to national security; and therefore b) the whole of the foreign policy establishment-State

${ }^{75}$ David Smock and Qamar ul-Huda, Islamic Peacemaking Since 9/11, United States Institute of Peace Special Report No. 218 (Washington, DC: USIP, 2009).

${ }^{76}$ William Inboden, “ Presidential Promotion of International Religious Freedom,” in "Religious Freedom and Foreign Policy,” ed. Dennis Hoover and guest editor Thomas Farr, special issue, The Review of Faith \& International Affairs Vol. 6, No. 2 (Summer 2008): 41.

${ }^{77}$ Ibid. Clinton approved the designation of China as a CPC in 1999. Bush approved the designation of Saudi Arabia as a CPC in 2004, and Uzbekistan in 2006, at a time when bilateral security cooperation was still at a premium.

${ }^{78}$ Hertzke, “International Religious Freedom Policy,” 20. Hertzke is quoting Farr in a 2007 Pew Forum panel.

${ }^{79}$ H. Knox Thames, Chris Seiple, and Amy Rowe, International Religious Freedom Advocacy (Waco, TX: Baylor University Press, 2009). 
as well as the Department of Defense, the military services, and the intelligence communityshould integrate religious freedom advancement into their respective bureaucratic mandates. ${ }^{80}$

\section{Conclusion}

The campaign for religious freedom marked a new era of engagement by faith-based groups in the public policy arena. A coalition of domestic religious groups successfully created a debate among policymakers, passed landmark legislation, created new structures in the U.S. foreign policy bureaucracy, and catalyzed a discussion on religious freedom. But despite the movement's intra- and interfaith appeal, American Muslims were not included relative to: a) the size of the community as a domestic minority religious group; and, b) the great attention given to Islamic governments and Muslim-majority countries as persecutors. To date, then, apart from the public service of a few individuals on USCIRF, and scattered meetings between community representatives and U.S. foreign policy officials, American Muslims have not contributed significantly to the cause of international religious freedom in terms of debate or action.

This chapter has argued that this problem is traceable to perceptions of religious bias extant in the movement's core constituency—including some of its leaders—and in the broad reluctance of the foreign policy bureaucracy to meaningfully engage the American Muslim community. But at least part of this lack of engagement is a result of the American Muslim community's lack of interest in the cause, and institutional inability to coalesce around any grassroots campaign. Chapter Two explains these points in the context of the incorporation of the community as a social and political entity in the United States, especially vis-à-vis the dramatic events of the last decade—-9/11, the Global War on Terror, and the invasions of Iraq and

${ }^{80}$ Chris Seiple, "Review of World of Faith and Freedom by Thomas Farr," in Journal of Church \& State, Vol. 51, Iss. 3 (Summer 2009): 535-536. 
Afghanistan —all of which have shaped the response of American Muslims to U.S. religious freedom policy. 


\section{CHAPTER TWO}

\section{THE POLITICAL INCORPORATION OF AMERICAN MUSLIMS}

Muslim Americans have not been meaningfully incorporated into the international religious freedom movement either at the grassroots or the institutional levels. As Chapter One detailed, this reality stems partly from the dynamics of the movement itself and partly from the orientation of the foreign policy bureaucracy. However, it also reflects the Muslim American community’s complex and on-going process of political incorporation.

American history scholar Gary Gerstle has defined political incorporation as "the process through which immigrants and their descendants have come to think of themselves as Americans with political rights and with a voice in politics, should they choose to exercise it.” ${ }^{1}$ Political incorporation occurs on three different levels: formal, political-cultural, and politicalinstitutional. At the formal level, an immigrant acquires the legal standing of citizenship, inherits specific rights, and becomes subject to certain duties. At the political-cultural level, individuals “come to feel as through they belong in the United States and can play a part in its democratic politics.” Finally, immigrants undergo incorporation at the political-institutional level when they seek political influence through establishing or joining their own institutions.

In this chapter, I apply Gerstle’s framework to Muslim immigrants and the subsequent development of the immigrant Muslim American community. At the political-cultural level, Muslim Americans have worked to demonstrate their loyalty to and proficiency in American ideals such as diversity, democracy, and religious freedom, while consciously feeling the weight of a general American uneasiness with their religion. Experiencing prejudice, discrimination, and

\footnotetext{
${ }^{1}$ Gary Gerstle, “The Political Incorporation of Immigrant Groups,” in American Arabs and Political Participation, ed. Philippa Strum (Washington, DC: Woodrow Wilson International Center for Scholars, 2004), 27.
} 
intimidation has helped drive the community to participate in local, state, and national politics and establish political organizations to represent Muslim American interests. Muslim institutions in the U.S. are still nascent, however, and relatively weak in comparison to those of other faith communities. Furthermore, political involvement to date has generally been limited to addressing domestic concerns, and expressing widespread (although not universal) dissatisfaction with U.S. foreign policy in the Muslim world.

This chapter includes treatment of both pre- and post-9/11 periods. The former is important in terms of contextualizing Muslim American attitudes during the original international religious freedom campaign from 1996-1998, before the events of 9/11 had dramatically raised the profile of the Muslim American community. 9/11 led to intense scrutiny of the communityfrom government and society—and provoked debates among Muslim Americans themselves, accelerating the efforts by which Muslim Americans have sought empowerment at the cultural and institutional level.

\section{Literature}

Growing interest in the Muslim American community, driven in large part by the events of the past decade, has generated numerous scholarly and popular works. Many Muslim Americans themselves have authored articles, opinion pieces, chapters, and entire books on the subject of Islam, democracy, terrorism, and politics, among other subjects. ${ }^{2}$ A number of government agencies and think tanks have produced wide-ranging reports on Muslim Americans drawing from established scholars and experts in the fields of history, sociology, political science, religious studies, and public policy. Particularly useful is the Chicago Council on Global

\footnotetext{
${ }^{2}$ See, for example Asma Gul Hasan, American Muslims: The New Generation, 2nd ed. (New York: Continuum, 2002); Feisal Abdul Rauf, What's Right with Islam: A New Vision for Muslims and the West, 1st ed. (San Francisco: Harper, 2004); and M.A. Muqtedar Khan, American Muslims: Bridging Faith and Freedom, 1st ed. (Beltsville, MD: Amana Publications, 2002).
} 
Affairs’ 2007 report Strengthening America: The Civic and Political Integration of Muslim

Americans, and the Woodrow Wilson International Center's 2005 Muslims in the United States:

Identity, Influence, Innovation. The Pew Center and Gallup both released comprehensive studies

of Muslim Americans in 2007 and 2009, respectively, which contain much valuable data on

demographics, attitudes, and opinions. For pre-9/11 context, I have drawn from the collections

The Muslims of America (1991) and Muslims in the West (2002) edited by Yvonne Haddad,

Professor of the History of Islam and Christian-Muslim Relations at Georgetown University’s

Center for Muslim-Christian Understanding, and one of the pre-eminent authorities on Muslims

in America. Finally, I make extensive use of the Encyclopedia of Islam in the United States,

edited by Jocelyne Cesari, and published in 2007 as the first encyclopedic reference source

pertaining to Islam and Muslims in America. ${ }^{3}$

Overview

Muslim migration to the United States has occurred in three major "waves” from 1875 to the present day. ${ }^{4}$ The first wave, from 1875 to 1918, brought laborers from the Levant-modern

${ }^{3}$ Task Force on Muslim American Civic and Political Engagement, Strengthening America: The Civic and Political Integration of Muslim Americans (Chicago: Chicago Council on Global Affairs, 2007); Philippa Strum, ed., Muslims in the United States: Identity, Influence, Innovation (Washington, DC: Woodrow Wilson International Center for Scholars, 2005); Yvonne Haddad, ed., The Muslims of America (New York: OUP, 1991); Yvonne Haddad, ed., Muslims in the West: From Sojourners to Citizens (New York: OUP, 2002); Pew Research Center, Muslim Americans: Middle Class and Mostly Mainstream (Washington, DC: Pew Research Center, 2007); Gallup, Muslim Americans: A National Portrait (Washington, DC: Gallup, 2009); Encyclopedia of Islam in the United States, ed. Jocelyne Cesari (Westport, CT: Greenwood Press, 2007).

${ }^{4}$ Jocelyne Cesari, “Introduction,” EIUS, xxvi-xxx; Nathan Fonder, "Immigration,” EIUS, 307311. Scholarly treatment of the subject differs in the number of waves, usually between three and five. For purposes of this essay, given the focus on the most recent decade, I use the more broad classification of three waves. Muslim presence in North America did not strictly begin in 1875, as scholars estimate that ten percent of the Africans forcibly brought to the colonies were Muslims, but the vast majority of these could not keep their identity under the brutal assimilation into a Christian slave-holding society. Nonetheless, this heritage has been claimed by some African-American Muslims as a source of religious identity. For a 
day Syria and Lebanon—fleeing economic hardship and strife brought on by religious violence and later World War I. ${ }^{5}$ The interwar years saw a more widely scattered collection from the regions of the former Ottoman Empire, and after World War II, increasing numbers of South Asians joined those arriving from the Middle East, Turkey, and the Balkans. In 1965 the Johnson administration relaxed the quota policy through the Immigration and Naturalization Act, which allowed greater numbers of highly qualified Muslims from Africa, Asia, and the Middle East to immigrate. The immediate fallout from 9/11 including the PATRIOT Act temporarily disrupted the pattern of steady immigration, but since 2005, the numbers have been back on the rise. In 2005 approximately 96,000 people from Muslim countries became U.S. citizens — the highest number in two decades. ${ }^{6}$

The total number of Muslim Americans in the U.S. has been an ongoing debate. No official figures exist because as a matter of policy neither the U.S. Census Bureau nor the Immigration and Naturalization Service ask questions about religious belief and affiliation in their documentation. The most comprehensive survey to date, the Pew Research Center’s 2007 report “Muslim-Americans” estimated that Muslims constitute $0.6 \%$ of the U.S. adult population, or 1.4 million Muslims 18 years or older. ${ }^{7}$ American Muslim advocacy groups, counting

primer on Muslim slaves, see Sulayman Nyang, Islam in the United States of America (Chicago: ABC International Group, 1999) for a descriptive overview of the scholarship on the subject.

${ }^{5}$ See Karen Leonard, "South Asian Leadership of American Muslims," in Muslims in the West for a brief discussion of the immigration of Punjabi Indians to the U.S. West Coast during the same time period.

${ }^{6}$ Fonder, "Immigration,” EIUS. It should also be noted that according to the Pew 2007 report a majority (61\%) of the total number of immigrant (foreign-born) Muslims in the U.S arrived in the last two decades.

\footnotetext{
${ }^{7}$ Pew Center, Muslim Americans.
} 
children, put the figure much higher, in the six to ten million range; the most reliable number is probably four million. ${ }^{8}$

The Pew report states that of the (adult) Muslim American population, 65\% are foreign born, with Arabs constituting the single largest sub-group, followed by South Asians, and then Iran. Of the remaining 35\% who are native-born, a majority (56\%) identifies themselves as black, likely representing the bulk of the African-American Muslim population. ${ }^{9}$ Sunni Muslims make up half of the total number of Muslim Americans (both foreign and native-born) at 50\%, Shiites just $16 \%$, and the remainder identifying themselves as "other" or "don't know." ${ }^{10}$ In addition to differences in ethnicity/nationality and sectarian affiliation, Muslim Americans divide on issues such as religious orientation, political ideology, and partisan commitments.

One of the major breakwaters that Muslim Americans have had to navigate in the search for an identity is the tension between immigrant and indigenous Islam, and specifically, AfricanAmerican Islam. The indigenous Muslim experience began with the mysterious Fard Muhammad in the early $20^{\text {th }}$ century. His better-known disciple, Elijah Muhammad, combined a powerful narrative of quasi-Islamic ritual with black consciousness in the founding of the Nation of Islam. For the better part of the century, foreign-born Muslims regarded the Nation of Islam as unorthodox and non-Islamic, not least for Elijah Muhammad’s heretical assumption of prophethood. After his death in 1975, his son W.D. Muhammad reorganized the Nation of Islam and carefully moved it to orthodox Sunni Islam. Now known as the Muslim American Society, this community nonetheless retains a deep consciousness of its roots in the American black

\footnotetext{
${ }^{8}$ Jocelyne Cesari, “Introduction.”

${ }^{9}$ The 2009 Gallup report has slightly different figures.

${ }^{10}$ Pew Center, Muslim Americans.
} 
experience, and its members jealously guard their prerogative to articulate a black American Islam against the tendency of immigrant Muslims to "[monopolize] the authority to define properly constituted Islamic life in the United States." ${ }^{11}$

Despite this historical tension, relations between the two communities have improved steadily over the last several decades through political cooperation, dialogue projects, and increasing linguistic and cultural familiarity of the other. Noting this dynamic, The Chicago Council on Global Affairs 2007 report on Muslim Americans stated that immigrant Muslims "have a great deal to learn from the successes of African American Muslims” in terms of institution-building and public communication. ${ }^{12}$

This chapter focuses on the political incorporation of immigrant Muslim Americans. The development of the African American Muslim community as a religious, social, and political entity is a complex story, and has been treated in depth by several scholars. ${ }^{13}$ African American Muslims may become a key factor in any development of an “American Islam,” with possible ramifications for the entire umma (global Muslim community). But any near-term impact on the religious and political practices of Muslim-majority countries is more likely to emanate from immigrant Muslim Americans who possess far greater credibility and influence in their home countries.

${ }^{11}$ Sherman Jackson, "Black Orientalism: Its Genesis, Aims and Significance for American Islam” in Muslims in the United States: Identity, Influence, Innovation, ed. Philippa Strum (Washington, DC: Woodrow Wilson International Center, 2005): 39.

${ }^{12}$ Task Force, 25. See also the Gallup 2009 report for a discussion of some reconciliation efforts.

${ }^{13}$ See for example Edward E. Curtis IV, Islam in Black America (Albany, NY: State University Press of New York, 2002); Sherman A. Jackson, Islam and the Blackamerican: Looking Toward the Third Resurrection (New York: OUP, 2005); Sulayman Nyang, Islam in the United States of America (Chicago: ABC International Group, 1999). 


\section{Political-Cultural Incorporation}

The political-cultural level of incorporation involves the production of a sense of belonging and empowerment. Individuals "come to feel as though they belong in the United States and can play a part in its democratic politics.” Through both formal and informal channels (and through voluntarism and coercion), immigrants become inculcated in American sensibilities, ideals, and values, sometimes discovering "powerful affinities between American culture, religion and politics and [their] Old World roots.” ${ }^{14}$

The first wave of immigrants, consisting mainly of laborers with limited education, underwent "accelerated assimilation," forced to take on the language, religion, and culture of the host Christian society to survive. A few mosques were built in regions where greater numbers of these Muslims settled, such as Michigan, Iowa, and New York, but few survived. The second wave, relatively better educated, was able to exercise more control over the religious and cultural influences on their families, and, by visiting their home countries more often, provide "a living correction to their heritage” for second and third generations. Post-1965 immigrants, especially those from South Asia, have more fully participated in American society "while preserving and even privileging a Muslim and Islamic identity.”"15

Integration has not been seamless. As Gerstle sagely reminds his readers, there is a difference between the "popular telling” of the American immigration experience and the real one. This difference betrays a contradiction. America has incorporated more immigrant groups than any other country, a truly remarkable and unique accomplishment, but native-born

\footnotetext{
${ }^{14}$ Gerstle, 28.

${ }^{15}$ Nada Unus, “Assimilation,” EIUS: 91-95; Jocelyne Cesari, “Introduction.” For more on the unique contributions of South Asian Muslims, see the aforementioned article by Karen Leonard.
} 
Americans have almost always discriminated against some racial or religious immigrant group, “making the process more difficult or incomplete."16

The Muslim American experience bears witness to the staying power of prejudice. Stories of suspicion, opposition, and hostility toward Muslims and Islam in the U.S. fit into a narrative some scholars have termed Islamophobia. Originally a European term linked to resentment of Muslim immigrants' socioeconomic integration, it describes a set of negative attitudes toward Islam and Muslims among non-Muslim Americans. ${ }^{17}$ According to the Chicago report:

Islamophobia is the contention that Islam is a monolithic bloc unresponsive to change and lacking commonalities with American values, that Islam is a violent political ideology rather than one of the world's major religions, and that discrimination against Muslims is therefore justifiable. ${ }^{18}$

As a social anxiety, ${ }^{19}$ Islamophobia manifests in three categories of discrimination: 1) racism and/or ethnic bias; 2) nationalism/xenophobia; and, 3) religious bias. American Muslims, especially immigrants, while susceptible to racist and ethnic slurs, have more often suffered from nationalistic fervor driven by concerns over national security, or religious bias stemming from

\footnotetext{
${ }^{16}$ Gerstle, 29. He notes that for most of its history, the United States banned groups defined as non-white from becoming citizens. Moreover, throughout the nineteenth century, and into the twentieth, majority Protestants harbored intense anti-Catholic bias, "[construing] Popery as one of the chief threats to the American republic.”

${ }^{17}$ William Wininger “Islamophobia,” EIUS,344-348.

${ }^{18}$ Task Force, 29.

${ }^{19}$ Peter Gottschalk and Gabriel Greenberg, Islamophobia: Making Muslims the Enemy (New York: Rowman \& Littlefield, 2008), 5.
} 
American Christian conceptions of Islam (by Protestants and Catholics). ${ }^{20}$ In turn, these attitudes have often been reflected in, and exacerbated by, American media.

First, reactions to national and international crises involving Islam and/or Muslims and American interests have frequently rebounded on Muslim Americans. Prior to 9/11, hate crimes and other public acts of discrimination against Muslims in the U.S. were relatively low, but association of Muslim Americans with extremism and terrorism rose following events such as the Iranian Revolution, the Gulf War (1990-91), the first World Trade Center bombings (1993), Oklahoma City (1995), and TWA Flight 800 (1996). ${ }^{21}$ The events of 9/11 were followed by a dramatic increase in hate crimes, attacks on property, and other acts of discrimination targeting Muslims. 9/11's impact on Muslims' political and social integration will be discussed in greater detail below.

Second, Western Christianity, including Protestant Christianity, has harbored particular prejudices toward Islam. Thomas Kidd, an expert on religion in American history, classifies historical views of Islam by American Protestants into three categories: 1) as a means to justify political or theological views; 2) with the goal of making converts; and, 3) as an essential piece in eschatological systems. In Kidd's assessment, the long praxis of engagement with Islam vis-à-vis political aims, missionary activity or end-of-times prophecy has unfortunately “revealed precious little courtesy or understanding.”22 Some of the more rigid views remain extant today, especially

${ }^{20}$ William Wininger, “Islamophobia.” In Europe, discrimination stems not only from the three factors mentioned, but also resistance to Muslims’ socioeconomic integration. Gottschalk and Greenberg suggest that the collective American concept of Islam was sown by European ideas and memories garnered from Christian Europe’s interaction with the Muslim east (Islamophobia,17-43).

21 Jesse Bradford, “Discrimination,” EIUS, 188-190. Discrimination against Jewish Americans was still higher in terms of reported incidents.

${ }^{22}$ Thomas Kidd, “Islam in American Protestant Thought,” Books \& Culture: A Christian Review, 12, num. 5 (Sept./Oct. 2006): 39-41. 
in evangelical circles. ${ }^{23}$ This is an important point because evangelicals formed the base of support for the international religious freedom movement. Yet their combative stance on Islamreal or perceived—has complicated multi-faith relations with Muslims and other groups. ${ }^{24}$

The media has often reflected and perpetuated prejudice toward Islam. Even before 9/11, public discourse on Islam is often a captive of a "media straitjacket” that either limited Muslims to specific roles within a stereotypical norm (e.g., terrorists, insurgents, oil tycoons), or shows them standing outside a non-stereotypical norm (i.e., antithetical to American values). Television, movies, and newspapers have resorted to caricatures of Muslims that quickly devolve into stereotypes, as when Muslims are equated with Arabs, or shown as medieval, duplicitous, and even evil. ${ }^{25}$ As the Chicago report states, some news coverage "presented without analysis...left the false impression that the extremists represent Islam and that Muslims generally approve of terrorism.”26 The report also calls attention to the problem of underreporting of Muslim protests and denunciations of violence, and the fact that anti-Muslim epithets by some pundits has gone

${ }^{23}$ Richard Cimino, "No God in Common: American Evangelical Discourse on Islam After 9/11,” Review of Religious Research, Vol. 47:2 (2005): 162-174. Cimino demonstrates a noticeable upsurge in evangelical literature after 9/11 emphasizing "sharper boundaries" between Islam and Christianity, and asserting that Islam is an essentially violent religion. Cf. also Pew Research Center polls "Public Expresses Mixed Views of Islam, Mormonism” (2007) and "Views of Islam Remain Sharply Divided” (2004), http://people-press.org/report/358/public-expresses-mixed-views-of-islam-mormonism and http://peoplepress.org/commentary/?analysisid=96 (accessed March 15, 2010). The number of white evangelicals holding an unfavorable opinion of Islam increased from 46 percent to 57 percent between 2004 and 2007. ${ }^{24}$ Cimino, 174. Despite the weight of entrenched theological positions within their community, some evangelicals are actively seeking cooperation with Muslim Americans on social justice issues in the U.S. For example, see the presentation by Chris Seiple, President of the Institute for Global Engagement (IGE), at the International Islamic University in Islamabad (IIUI), Pakistan: http://www.blip.tv/file/3121876. IGE featured Evangelical-Muslim relations in its last Global Leadership Forum, an annual two-day plenary and panel forum held in Washington, DC.

${ }^{25}$ Gottschalk and Greenberg, 61-88.

${ }^{26}$ Task Force, 29-30. 
unchallenged by Muslims and non-Muslims alike. ${ }^{27}$ Even when aimed at Islam broadly, and not at themselves, Muslim Americans feel the sting of such bias deeply. ${ }^{28}$ Yet experiencing prejudice, discrimination, and intimidation has helped drive the community to participate in local, state, and national politics and establish political organizations to represent Muslim American interests.

\section{Political-Institutional Incorporation}

Immigrants undergo incorporation at the political-institutional level when they seek political influence through establishing or joining their own institutions. The collective focus of the immigrant Muslim community began with religious and educational needs and has only recently expanded to political organizations representing American Muslim identity and interests at a national level. ${ }^{29}$

The initial priority for most immigrants was securing physical capacity for religious rituals and instruction. The long-term presence of facilities dedicated to Islamic rituals and education began with the second wave of immigrants. The first mosque in the United States specifically designed and built for Islamic purposes was the Moslem Mosque, erected in

\section{${ }^{27}$ Ibid.}

${ }^{28}$ Sahar Aziz, "Free Muslim Americans from Collective Punishment,” altmuslim.com, February 10, 2010, www.altmuslim.com (accessed February 10, 2010); Geneive Abdo, "Separate But Unequal," in The Washington Quarterly, Vol. 28:4 (Autumn 2005): 7-17; Hadia Mubarak, "How Muslim Students Negotiate Their Religious Identity and Practices in an Undergraduate Setting," Social Science Research Council, May 8, 2007, http://religion.ssrc.org/reforum/ (accessed March 15, 2010). Cf. Daniel Pipes, "Are Muslim Americans Victimized?” in Commentary, Vol. 110, Iss. 4 (November 2008): 33-37, http://0www.proquest.com.library.lausys.georgetown.edu (accessed March 15, 2010). Pipes, a Middle East scholar, long time critic of Islamic political thought, and an icon for neo-conservatives, has questioned the scope and degree of prejudice toward Muslims (before 9/11). While Pipes' analysis might help check excess in narratives of Muslim American victimization, it cannot refute the reality of a wide-spread social anxiety toward Islam among Americans that has shaped the political incorporation of Muslims in the United States.

${ }^{29}$ Zahid Bukhari, Director, American Muslim Studies Program, Georgetown University, class lecture, November 2007. 
Highland Park, Michigan in $1921 .^{30}$ Many of the earliest mosques did not survive, but to date, approximately 2,300 mosques, Islamic schools, and organizations exist throughout the fifty states. $^{31}$

The establishment of mosques and Islamic schools has generated challenges for American Muslims. Many Muslim communities around the U.S. have reported opposition to their mosques and schools from local neighborhoods, and some have been targets of vandalism or arson (especially after 9/11). ${ }^{32}$ In many cases, Muslims have been able to assuage concerns by dialoguing with neighborhood councils, holding “open mosque” nights, and securing support from other local religious groups. ${ }^{33}$ However, in some instances, local and national "Islam watchdog groups” persist in fueling controversy over new or existing mosques and schools. ${ }^{34} \mathrm{~A}$ typical example is the Militant Islam Monitor’s characterization of the Khalil Gibran International Academy—New York City's first public school dedicated to the study of Arabic language and culture—as backed by "hard core Islamists [and] their leftist sympathizers.” ${ }^{35}$

${ }^{30}$ Saeed A. Khan, “Mosques,” EIUS: 427-432.

${ }^{31}$ U.S. Department of State Bureau of International Information Programs, Being Muslim in America (Washington, DC: Government Printing Office, 2009).

${ }^{32}$ Saeed A. Khan, "Mosques.”

${ }^{33}$ See also Leadership Group on U.S.-Muslim Engagement, Changing Course: A New Direction for U.S.-Muslim Relations (Washington, DC: Search for Common Ground and Consensus Building Institute, 2008), 87. The Canadian Broadcasting Corporation aired a series entitled Little Mosque on the Prairie portraying the humorous side of mosque-community relations in post-9/11 North America.

${ }^{34}$ For example, see Michael Paulson, "Mosque Open Its Doors as Controversy Fades,” Boston Globe, September 15, 2008.

${ }^{35}$ MilitantIslamMonitor.org, "Khalil Gibran School Arabic public school with clerical advisory board must be shut down as religious school," May 8, 2007, http://www.militantislammonitor.org/article/id2872 (March 10, 2010). On March 15, 2010, the Equal Employment Opportunity Commission ruled that the New York City Department of Education discriminated against the founding principal of the afore-mentioned Arabic-language school in Brooklyn by forcing her to resign. 
Federal scrutiny of mosque finances can also invite negative attention, stoking fears among members that their institution will be perceived as being "tainted by terrorism."36

The second priority has been the establishment of institutions that would help preserve and develop Muslim identity in America, and articulate and represent an American Muslim interest at the national level. The Muslim Students Association (MSA) and the Islamic Society of North America (ISNA) stand out as the premiere nonpolitical social organizations dedicated to creating the "psychological space and institutional infrastructure for a permanent Muslim presence in America. ${ }^{37}$ Established in 1981 in Plainfield, Indiana, ISNA grew out of the MSA as Muslim students graduated and expanded their religious, social, civic, and professional interests, and today counts 300 affiliated Islamic centers and associations. ${ }^{38}$ Due to ISNA's standing as the flagship Muslim umbrella organization in the United States, the government, as well as political candidates and parties, have cultivated relationships with it as a means of recognizing and

\footnotetext{
${ }^{36}$ Anne Bernard, “Concern at a School in Building Tied to Iran,” New York Times, November 14, 2009.

${ }^{37}$ Nada Unus, "The Muslim Student Association of the United States and Canada,” EIUS: 453455. See also Gutbi Mahdi Ahmed, "Muslim Organizations in the United States," in The Muslims of America. Founded in 1963, the Muslim Student Association grew out of the shared experiences of visiting Arab students on U.S. and Canadian campuses, and the common desire to both preserve their Muslim identity in a non-Muslim culture and promote Islam within American society. In the mid-1990s, an influx of second-generation Muslim students propelled a turn from overseas to domestic concerns, and the MSA began to actively "publicize and synthesize congruence between its members' Muslim and American identities... [and] shared moral and political values between Islam and the United States.” Some MSA members were members of, or were heavily influenced by, the Muslim Brotherhood in their home countries before emigrating. These connections have been detailed in somewhat alarmist fashion by Zeyno Baran of the Hudson Institute in "The Muslim Brotherhood's US Network," Current Trends in Islamist Ideology, Vol. 6 (March 14,2008): 95-122.

${ }^{38}$ Nada Unus, “Islamic Society of North America,” EIUS: 341-343. See also aforementioned Gutbi Ahmed article. ISNA, which cut financial ties with Saudi Arabia after the first Gulf War, is considered to represent a "a traditionally based moderate orientation of Islam." Its mission statement declares that: "ISNA is an association of Muslim organizations and individuals that provides a common platform for presenting Islam, supporting Muslim communities, developing educational, social and outreach programs and fostering good relations with other religious communities, and civic and service organizations."
} 
engaging the American Muslim community broadly. ${ }^{39}$ Smaller organizations such as the Islamic Circle of North America (ICNA), while less endowed and more ethnically-oriented, nonetheless have played important roles in dawa (missions), tarbiyya (religious learning), social services for Muslims and non-Muslims, and interfaith activities. ${ }^{40}$ These and similar organizations paved the way for intra-Muslim focus and coordination in establishing actual political organizations with national (if slight) constituencies.

Despite the growth of national Muslim social organizations, as recently as the 1980s, participation in American politics remained a divisive issue within the American Muslim community. The debate was shaped not just by religious views, but other variables such as racial identification, discrimination, immigration status, and orientation toward U.S. foreign policy. For first generation immigrants especially, initial obstacles included lack of comfort or knowledge of American political practices; general resistance to assimilation; and limited proficiency with English. At the same time, opponents of integration and participation warned of the dangers of a diluting one's deen (religion) and succumbing to lower morals, secularism, and the betrayal of the umma. Meanwhile, any African American Muslims, "though overtly political in some aspects, remained deeply distrustful of American society and the U.S. government.” ${ }^{41}$

${ }^{39}$ Ibid. For example, Karen Hughes spoke at the 2005 ISNA annual convention as part of the Bush administration's public diplomacy initiative. ISNA president Ingrid Mattson spoke at the 2008 Democratic National Convention, and served as the Muslim representative during the National Prayer Service following the 2009 inauguration of President Barack Obama.

${ }^{40}$ Nada Unus, “The Islamic Circle of North America,” EIUS, 336-339.

${ }^{41}$ Jesse Bradford, “Politics,” EIUS, 502-505. Opponents of integration and participation included various Sufi, Salafi, and dawa-oriented groups such as Tabligh Jama'at, Islamic Assembly of North America, Qu'ran and Sunnah Society, Hizbul Tahrir, Muslim American Society (not the African American Muslim organization by the same name). Proponents included ICNA, ISNA, CAIR, MPAC, AMC, AMA, and Imam W.D. Mohammed's Muslim American Society. 
The first major Muslim American political organizations were founded in the late 1980s and early 1990s: the Muslim Public Affairs Council (MPAC) in 1988, the American Muslim Alliance (AMA) in 1989, the American Muslim Council (AMC) in 1990, and the Council on American-Islamic Relations in 1994. These organizations sought to combat negative stereotypes of Islam in public discourse, defend American Muslims against discrimination and defamation, and increase political education and grassroots mobilization through public campaigns, lobbying, annual reports, voter registration, and electoral strategies. The AMC in particular worked to raise Muslim participation in the political process through regular interaction between public officials and Muslim representatives. The rise of these groups in the 1990s, and their emphasis on domestic concerns, paralleled Muslim Americans’ growing perception that “religious accommodations" for Muslims in the U.S. had "fallen short” of constitutional ideals. ${ }^{42}$ Ironically, the campaign for international religious freedom reached its groundswell just as American Muslims were beginning to seriously tackle issues of civil and religious liberties within the U.S. During the 1990s, examples of growing Muslim American representation in local, state, and national forums included:

- Opening legislatures with prayer (Congress, 1991-1993; the Michigan House of Representatives, 1999)

- Introducing Muslim chaplains and Islamic literature in the armed services

- Presidential Eid greetings to the global and domestic Muslim community

- Presidential Iftaar dinners (Hillary Clinton hosted the first dinner in 1996)

- Town meetings between local Islamic centers and elected officials

- Appointment of the first Muslim ambassador, to Fiji, in 1999

\footnotetext{
${ }^{42}$ Mohammed Nimer, “American Muslim Organizations: Before and After 9/11,” in Muslim in the United States: Identity, Influence, Innovation, ed. Philippa Strum (Washington, DC: Woodrow Wilson International Center for Scholars, 2005): 7.
} 
- Protests against discriminatory remarks made by military/elected officials

- $\quad$ Criticism of government security initiatives

- Addressing local issues, e.g. zoning, parking at mosques, etc

- Voter registration

- Endorsing candidates and fundraising

- Lobbying for Jerusalem

The goal of these and other kinds of participation was empowerment. ${ }^{43}$ By the late 1990 s, groups such as the AMC, CAIR, and MPAC had succeeded in raising the profile of the community in public discourse, sparking debate over the integration of Muslims into a nonMuslim society, and increasing support from the Muslim community for involvement in public policy forums. ${ }^{44}$ Yet their capacity to actually influence policy and politics remained slight due to many of the typical problems facing young institutions: vague or overly ambitious goals; narrowly defined constituencies; limited funding; and, lack of policy analysis and legislative experience. ${ }^{45}$ Especially in regard to funding, Muslim organizations remained considerably weaker relative to more established Jewish and Christian groups. ${ }^{46}$ Moreover, despite the importance of coalition building in interest group politics, few alliances had been made with non-

${ }^{43}$ Mohamed Nimer, "Muslims in American Public Life," in Yvonne Haddad, ed., Muslims in the West: From Sojourners to Citizens (New York: OUP, 2002): 183.

${ }^{44}$ Ibid.; Nate Spannaus, "Patriotism,” EIUS, 492-494. A post 9/11 poll found that approximately 96\% of American Muslims supported involvement in the political process.

${ }^{45}$ Task Force, 57-58.

${ }^{46}$ Robert Marquand and Lamis Adoni, "Muslims Learn How to Pull Political Ropes," Christian Science Monitor, February 5, 1996. 
Muslim groups, with the exception of temporary initiatives with civil rights groups such as the American Civil Liberties Union (ACLU). ${ }^{47}$

September $11^{\text {th }}$

The tragedy of 9/11 thrust the Muslim American community into the public spotlight. Muslim American individuals, groups, and organizations came under intense scrutiny by both government and society. As the administration of George W. Bush escalated an existing counterintelligence campaign against known terrorist organizations into a full-blown "Global War on Terror," many American Muslims felt as if they were on the front lines. Social anxiety over Islam and Muslims reached unprecedented levels, the government acquired vastly increased powers of law enforcement, and the country went to war with two Muslim nations. ${ }^{48}$

In many respects, Muslim Americans stood poised on the brink of repeating the German American experience during World War I, when wartime fears-intentionally fanned by the government—inflicted a "mortal cultural wound" on a group of immigrants proud of their combined Old and New World heritage. German Americans responded to public vitriol by withdrawing from the active expression of their "cultural pluralism” and adopting a quietist stance. $^{49}$

In contrast, the response of Muslim Americans to 9/11 has been greater politicization. A sense of urgency has driven Muslim Americans towards cooperation within the community and more participation in the political process. Donations to American Muslim political organizations

\footnotetext{
${ }^{47}$ Nimer, “American Muslim Organizations,” 11.

${ }^{48}$ Part of the rhetorical mix at the time were the public statements made by then-President Bush that Islam was a religion of peace, and that the 9/11 suicide teams were "hijacking Islam;" unfortunately no study that I am aware of has attempted to assess the affect these statements had in terms of domestic attitudes toward Islam.

${ }^{49}$ Gerstle, 34-35.
} 
jumped considerably in the years after 9/11, reflecting the community's growing conviction that public persuasion and political empowerment suited their needs as never before. ${ }^{50}$ At the same time, an evolving American foreign policy vis-à-vis the Muslim world has resulted in expanded opportunities for Muslim Americans to affect the shape and direction of that policy.

The tragedy of $9 / 11$ generated immediate aftershocks. In the year following $9 / 11$, the number of hate crimes documented by the Federal Bureau of Investigation (FBI) increased sixteen-fold; attacks on property rose by twenty percent; and the Equal Employment Opportunity Commission (EEOC) received double the amount of official complaints. These were only the reported incidents; the actual number was probably much higher. ${ }^{51}$

Almost ten years after 9/11, at a level far removed from hate crimes and public acts of discrimination, the American public remains uneasy about Islam and Muslims. One of the most recent opinion polls found that Americans are more than twice as likely to report having negative feelings toward Muslims as toward Buddhists, Christians, or Jews. ${ }^{52}$ Fifty-three percent of Americans say their opinion of Islam is either "not too favorable” (22\%) or "not favorable at all” (31\%). Forty percent admit to having “very little knowledge” (40\%) or “none at all” (23\%).

Lastly, significant majorities disagree with the statements that: a) most Muslims are accepting of other religions (66\%); and, b) most Muslims believe women and men should have equal rights (81\%). However, the 2007 Pew survey noted that expressions of support offered to American Muslims were "virtually identical” to expressions of intolerance or bigotry. ${ }^{53}$

\footnotetext{
${ }^{50}$ Nimer, “American Muslim Organizations,” 14-15.

${ }^{51}$ Bradford, 188-190.

52 The figures in this paragraph are taken from the Muslim West Facts Project, Religious Perceptions in America (Washington, DC: Gallup and The Coexist Foundation, 2009): 4-5, 18.

${ }^{53}$ Pew Center, Muslim Americans, 38.
} 
On a broad level, public discourse around Islam after 9/11 pushed many Muslim Americans to better articulate their allegiance as U.S. citizens, their views on issues such as Islam, democracy, human rights, and U.S. foreign policy, and their perception of themselves as a distinct part of the Muslim umma. Muslim American organizations moved quickly to denounce the 9/11 attacks (and subsequent domestic acts of terrorism done in the name of Islam), signal their support for the United States government, and demonstrate their cooperation in domestic and international efforts to combat terrorism. Many began or supported campaigns to disassociate Islam from terrorism, and in July 2005, when the Fiqh Council of North America - the highest ranking body of Islamic legal scholars in North America—issued a fatwa (religious ruling) against extremism and terrorism, 145 organizations subsequently endorsed it. ${ }^{54}$ At the same time, “with respect to foreign policy, AM’s faced the challenge of expressing their (widespread by not universal) opposition to the wars in Afghanistan and Iraq... without appearing unpatriotic or sympathetic to anti-American forces.” 55

9/11 similarly complicated relations between the U.S. government and the American Muslim community while sparking positive developments. American Muslims, who had previously opposed the 1996 Secret Evidence legislation, were particularly affected and upset by the PATRIOT Act, which was decried for legalizing law enforcement tactics that many felt violated constitutional and legal principles. The act also made immigration more complex by increasing bureaucratic investigations for Muslim applicants. The Chicago report, referencing government data, states that since 9/11, over 80,000 Arab and Muslim non-national residents

\footnotetext{
${ }^{54}$ Task Force report, 37-39.

${ }^{55}$ Erzen Ocncel, “US Foreign Policy in the Middle East” EIUS, 414-421. Ocncel notes polls done by Zogby that show that American Muslims believe US foreign policy has been "constantly aggressive” toward Muslims in the Middle East, targeting "both Islamic countries and Muslims.”
} 
have been required to undergo fingerprinting and registration, 8,000 have been identified for questioning, about 5,000 have been arrested or detained, and at least 400 have been criminally charged in terrorism-related investigations. ${ }^{56}$

In response to increased government scrutiny of Muslim immigrants, mosques, schools, and other institutions (including charitable organizations), Muslim American groups sought increased contact with various departments and agencies, including the Department of Justice, Homeland Security, and the FBI to discuss concerns and procedures. ${ }^{57}$ At the local level, Muslim citizen groups began more frequent and regular interaction with police departments and other law enforcement offices. High ranking public officials, including the head of the FBI, have publicly commended the American Muslim community for its efforts in combating the threat of terrorism, although relations between that agency and Muslim organizations continues to be subject to periodic flare-ups. ${ }^{58}$

In addition, U.S. government officials have begun reaching out to national Muslim groups such as ISNA and recruiting Muslim Americans for public diplomacy initiatives to Muslim-majority countries. The U.S. government, the think tank community, and American Muslims themselves have increasingly voiced the idea that the community can be an effective conduit to the Muslim world. ${ }^{59}$ Efforts to connect Muslims in the U.S. with Muslims abroad had

\footnotetext{
56 Task Force, 28-29.

${ }^{57}$ Ibid., 37 and 40.

58 Ibid., 38; Jacqueline Salmon, “Muslim Americans at Odds Over FBI Contact,” Washington
} Post, March 28, 2009.

59 See for example Brookings Institution, "Karen Hughes and American Muslims: Alliance Against Extremism,” Brookings Institution, September 12, 2005, http://www.brookings.edu/opinions/2005/0912islamicworld_khan.aspx (accessed December 1, 2008); Hady Amr and P.W. Singer, Restoring America's Good Name: Improving Strategic Communications with the Islamic World (Washington, DC: Brookings Institution, 2006); Rep. Keith Ellison (MN), U.S. 
been in operation for decades, but 9/11 escalated the rhetoric around and implementation of such efforts, which are generally framed as servicing American interests in the war against terror and the promotion of democracy. ${ }^{60}$

Since 9/11, then, the spotlight on Muslim Americans has simultaneously created challenges and opportunities. Increased public scrutiny has catalyzed American Muslim introspection and a more cohesive articulation of the community’s political aspirations, which have been realized in a number of new ways. In 2005 the first Muslim was elected to Congress, and a second followed in 2008. Despite perceptions that both John McCain and Barack Obama snubbed Muslim Americans in the 2008 presidential election, as President the latter has publicly called attention to Muslim Americans’ positive contributions to American society in front of domestic and foreign audiences, sought Muslim American input on engaging Muslim-majority countries, and appointed several Muslim Americans to senior positions. ${ }^{61}$ While Muslim political

Congress, Hearing of the Senate Committee on Foreign Relations, "Engaging With Muslim Communities Around the World," (February 26, 2009), http://www.gpo.gov/fdsys/pkg/CHRG-111shrg60/pdf/CHRG111shrg60.pdf (accessed February 26, 2009).

${ }^{60}$ For example, the State Department's Country Report on Terrorism 2007, http://www.state.gov/s/ct/rls/crt/2007/104115.htm (accessed December 1, 2007) defines the State Department's Strategic Speakers Initiative as follows: “The Strategic Speakers Initiative (SSI) identifies, recruits, and programs prominent U.S. experts to engage foreign opinion leaders on key strategic themes such as democracy and rule of law, terrorism and security, energy, the environment, and trade and development. A subset of this program is the Citizen Dialogue Program, in which Muslim-American citizens share their personal stories with fellow Muslim cohorts in strategically important countries, many of whom are not aware of the strength and diversity of Muslim life in America.” (emphasis added)

${ }^{61}$ Andrea Elliott, "Muslim Voters Detect a Snub from Obama,” New York Times, June 24, 2008. See also Barack H. Obama, "Inaugural Address," Washington, DC, January 21, 2009, and "Remarks by President Obama to the Turkish Parliament,” Turkish Grand National Assembly Complex, Ankara, Turkey, April 6, 2009, www.whitehouse.gov (accessed June 6, 2009). See also Glenn Kessler and Jacqueline L. Salmon, "Using New Language, President Shows Understanding for Both Sides in the Middle East," Washington Post, June 5, 2009. See also Scott Wilson, "Obama Names Envoy to Islamic Conference," Washington Post, February 14, 2010. Cf. Cal Thomas, "Who is Rashad Hussain,” Washington Examiner, February 18, 2010, and Marc Lynch, "The Smearing of Rashad Hussain,” ForeignPolicy.com, February 23, 2010, http://lynch.foreignpolicy.com/posts/2010/02/23/the_despicable_smearing_of_rashad_hussein (accessed February 25, 2010). 
organizations remain relatively young and inexperienced relative to the powerful lobbies of other faith communities, Muslim Americans’ permanence on the American political scene seems assured. $^{62}$

\section{Conclusion}

Over the last 130 years, Muslims from around the world have become part of the history of expansive immigration that is the heritage of the United States. Muslims now constitute approximately one percent of the U.S. population, a relatively small number, but their presence has commanded significant attention due to long-standing indigenous religious biases and heightened alarm over national security. 9/11 dramatically raised the community's profile, bringing intense—and often negative—-governmental and societal scrutiny. Muslim Americans have experienced many positive expressions of support from the American public before and after 9/11; nonetheless, they have faced a substantial challenge in integrating into a majority nonMuslim culture.

Muslim Americans’ experience of disjuncture between their “Old World” heritage and American culture, society, and politics echoes that of previous immigrant groups. Some of these groups have responded through quiescence, while others have taken up participation in American cultural and political life. Muslim Americans have followed the latter response, moving away from early quietude and progressively seeking change by establishing policies and institutions that could overcome alienation and make them "feel” as though they belonged in the United States.

${ }^{62}$ Anecdotally, both the youth and the vibrancy of Muslim political life was evident at ISNA's 2009 Annual Convention - held on Fourth of July weekend in Washington, DC — with one out of ten panels on political activism. The panels were composed according to members' feedback, suggesting that political participation ranked high on the list of current concerns. 
In particular, Muslim Americans have sought empowerment in order to realize domestic religious freedom. The experience of institution building to fight discrimination and to achieve a fuller recognition of religious and civil liberties specific to Muslims parallels the intellectual exploration of the linkage between Islamic principles and religious freedom. Thus, as Aziz Huq points out, "some of the most important reflections on Islam and human rights are coming from a liberal, democratic, political environment.”63 Chapter Three will delve deeper into the exploration of religious freedom by Muslim intellectuals living and writing in America.

${ }^{63}$ Aziz Huq, “Human Rights,” EIUS, 297-300. 


\section{CHAPTER THREE}

\section{AN AMERICAN ISLAMIC DISCOURSE}

As Muslims in America have undergone the process of political incorporation, they have explored a synthesis of the principles of democratic, constitutional government, American religiosity, and Islamic values. This discourse, still nascent during the first groundswell towards international religious freedom, was overlooked and ignored until the events of the past decade sharpened awareness of the need to confront extremist ideology in an age of rapid globalization and increasingly dense pluralism. Now, post-9/11, the theoretical accounts that American Muslims have formulated in defense of religious freedom may provide an important new conceptual tool in service of that end.

This chapter summarizes the thought of three leading American Muslim intellectuals on religious freedom—Abdulaziz Sachedina, Muqtedar Khan, and Khaled Abou El Fadl. The review brackets substantial questions: What do they base their argument on? What is their epistemology? Are their methods and conclusions accessible and/or relevant? What does religious freedom mean practically? Finally, how do they deal with tension between their theory and countering arguments?

This analysis includes the work of American Muslim intellectuals for two reasons. First, intellectuals in general merit attention as a special class of individuals whose activities provide "broad principles for criticizing conditions and institutions and also the general foundations for the transformation of society." ${ }^{1}$ Intellectuals have long walked the line between dissenting from the status quo and affirming it. In the history of Islam, the ulama have traditionally assumed the

\footnotetext{
${ }^{1}$ John Esposito and John Voll, Makers of Contemporary Islam (New York: Oxford University Press, 2001), 5.
} 
role of intellectuals. Second, today, a new style of Muslim intellectual exists who seeks societal transformation "within a framework of ideologies and programs that could be defined as authentically Islamic.”2 ${ }^{2}$ The focal point for many of these intellectuals is the debate over political governance-and more specifically, the compatibility of Islam and democracy, with its concomitant principles of pluralism, civil liberties, and human rights. In a 2007 essay, Muqtedar Khan categorized Islamic democratic discourse according to four groups of actors: activists, theologians, philosophers, and jurists. ${ }^{3}$ Only the last three, he claimed, were making substantial theoretical contributions to the continuing debate over Islam and democracy.

I use Khan’s schema in order to analyze American Muslim discourse on religious freedom, which is an important sub-set of Islamic democratic discourse. By taking Sachedina, Khan, and El Fadl to represent theologians, philosophers, and jurists respectively, and crossanalyzing their discussions of religious freedom, I seek to: a) highlight the range of theory available for American Muslims; b) identify potential strengths and weaknesses vis-à-vis religious freedom promotion in each approach; c) identify key differences and similarities among American Muslim thinkers; and, d) explore the possibility for a "coherent theoretical stand" on which American Muslims can promote international religious freedom.

This chapter is organized uniformly. For each author, I will provide a very brief biographical sketch, and a summary of key ideas and arguments taken from two to four selected writings. The section closes with a reflection on each author, and a further analysis that links common themes and tracks divergences.

\section{${ }^{2}$ Ibid., 20.}

${ }^{3}$ M.A. Muqtedar Khan, “The Politics, Theory, and Philosophy of Islamic Democracy,” in Islamic Democratic Discourse: Theory, Debates, and Philosophical Perspectives, ed. M.A. Muqtedar Khan (Lanham, MD: Lexington Books, 2006), 157. 


\section{Theologians}

Theology in Islam, or kalam, has always been intertwined with the interpretation and explanation of the Quran, tafsir. ${ }^{4}$ Thus, modern theologians appeal to the Quran directly to build their Islamic democratic discourse. Abdulaziz Sachedina has exemplified this approach in his teaching and writing over the last 35 years. Born in Tanzania of Shiite Indian Muslim heritage, Sachedina studied at the Aligarh Muslim University in India, the Ferdowsi University of Mahshad in Iran, and the University of Toronto. Once a student of Dr. Ali Shariati in Iran, in 1998 he was criticized by Grand Ayatollah Sistani (Iraq), who issued a statement advising Muslims not to listen to Sachedina's talks or ask him questions about religious matters. His research has touched on Islamic theology, jurisprudence, bioethics, and architecture, as well as Islam and interfaith relations, human rights, and democracy. Sachedina has served on multiple advisory and editorial boards, chaired the board of the Center for the Study of Islam and Democracy, and advised the drafters of the 2005 Constitution of Iraq. Sachedina now resides as Frances Myers Ball Professor of Religious Studies at the University of Virginia. ${ }^{5}$

Sachedina has written numerous books and articles that address religious freedom in the context of Islam and democracy. Early in his career Sachedina explored Qur'anic principles of interfaith relations, specifically between Muslims, Christians, and Jews. In more recent years his writings, still using Qur'anic principles, examined the viability of religious pluralism in the context of political pluralism and the public square. The later writings, while consonant with his initial works, go further in arguing the possibility, and necessity, of religious freedom in an

\footnotetext{
${ }^{4}$ Paula Skreslet and Rebecca Skreslet, The Literature of Islam: A Guide to the Primary Sources (Lanham, MD: Scarecrow Press, 2006), 55.

${ }^{5}$ Biographical information obtained from University of Virginia, “Abdulaziz Sachedina,” http://people.virginia.edu/ aas/ (accessed November 5, 2009); and Wikipedia, “Abdulaziz Sachedina,” http://en.wikipedia.org/wiki/Abdulaziz_Sachedina (accessed November 5, 2009).
} 
Islamic public order. It is the later writings, notably a book authored in conjunction with the Center for Strategic and International Studies in 2001 entitled "The Roots of Islamic

Democracy,” and a 2006 essay entitled "Islam in the Public Square” that will be examined below.

Sachedina unambiguously affirms the freedom of conscience and religion, the “cornerstone of democratic pluralism” and "fundamental to the Koranic vision of religiousity.” In this he echoes other Muslim thinkers who argue that true freedom alone authenticates belief. ${ }^{7}$ For Sachedina, the practical application of this principle is the freedom to choose, change, or reject one's religion — and the right to articulate one's religion in the public square. ${ }^{8}$ Sachedina is critical of liberal political theory that would deny religion any space in the public square ${ }^{9}$, Yet he acknowledges a need to set this engagement, and religious freedom in general, within the boundaries of public order. ${ }^{10}$ This order is not the exclusive jurisdiction of one religious community; it is a consensus worked out with "spiritual equals" (i.e., those outside the specific

\footnotetext{
${ }^{6}$ Abdulaziz Sachedina, “The Role of Islam in the Public Square: Guidance or Governance?” in Islamic Democratic Discourse: Theory, Debates, and Philosophical Perspectives, ed. M.A. Muqtedar Khan (Lanham, MD: Lexington Books, 2006), 180-181.

${ }^{7}$ See the collection of essays edited by Mehran Kamrava, The New Voices of Islam: Rethinking Politics and Modernity (Berkeley: University of California Press, 2006), especially those by Kadivar and Talbi.

${ }^{8}$ Abdulaziz Sachedina, The Islamic Roots of Democratic Pluralism, (New York: Oxford University Press, 2001), 100; “The Role of Islam in the Public Square,” 181.

${ }^{9}$ Cf. Yves Simon, A General Theory of Authority (Notre Dame: University of Notre Dame Press, 1980): "Whoever holds that society must refrain from any act relative to transcendent truth, and that the search for such truth must be neither directed nor helped in any way by society, is a liberal. And whoever holds that society normally should be concerned with transcendent truths, or some of them, has rejected the liberal notion." But Simon acknowledges that: "in the concrete history of ideologies adherence to the liberal principle admits of many degrees"-whereas Sachedina puts the question in reductionistic terms: "[In] the secularist foundation of a public order...all considerations drawn from belief in God or other sacred authority in one's private life are excluded from the administration of public life" ("The Role of Islam in the Public Square,” 181).

${ }^{10}$ Sachedina, “The Role of Islam in the Public Square,” 176.
} 
religious community) according to the "universal guidance” that is accessible by reason. ${ }^{11}$ From this "universal guidance” flow "ethical-moral” prescriptions to advance the common good. In a Muslim-majority context, the principle of separate jurisdictions inherent in Sharia provides the "functional secularity" that can manage the tension between private and public acts of faith. ${ }^{12}$

Sachedina states that the Muslim world has not yet realized this vision because of exclusivist theology: "The fundamental problem, as reflected in the classical formulation of Muslim political identity, is religious authoritarianism founded upon an exclusive salvific claim.” ${ }^{13}$ The answer is an inclusive theology. Sachedina bases his theological argument on direct appeals to the Koran. He explicitly defends his reliance on the Qur'an “as the normative source of theology of inclusiveness,” and, less directly, his right to exercise ijthihad. ${ }^{14}$ Somewhat unexpectedly, he bases his defense on the model of Sayyid Qutb, the now well-known provocateur of the Egyptian Muslim Brotherhood, who insisted on each individual Muslim’s responsibility to exercise free will in learning and acting on God's will. Qutb wrote a thirtyvolume exegesis of the Qur'an despite his lack of formal religious credentials. Sachedina emulates Qutb in appropriating the right to interpret the Qur' an but arrives at much different conclusions. ${ }^{15}$

\footnotetext{
${ }^{11}$ Sachedina, “The Role of Islam in the Public Square,” 181.

${ }^{12}$ Sachedina, “The Role of Islam in the Public Square,” 174, 186.

${ }^{13}$ Ibid., 175.

${ }^{14}$ Sachedina, The Islamic Roots of Democratic Pluralism,19-21, 26.

${ }^{15}$ Ibid.
} 
The key to this inclusive soteriology is universal moral guidance. God provides universal moral guidance to all humanity and specific revelatory guidance to certain communities. ${ }^{16}$ The former offers "salvific efficacy” to "all who have this divine religion, regardless of formal religious affiliation.” ${ }^{17}$ Sachedina cites prominent modernist Muslim scholars such as the Sunni Muhammad Abduh (d. 1905) and Muhammad Rashid Rida (d.1935), and Shiite Muhammad Husayn al-Tabatabi'I (d. 1982) as defenders of this "pluralist thrust” of Islam. ${ }^{18}$

The Qur’an’s “universal discourse” calls upon humanity to acknowledge its God-given capability to discern right and wrong. ${ }^{19}$ This discourse, because it appeals to the basic moral condition of humans everywhere transcends religious differences: inherent universal morality bridges private spirituality and interpersonal relations. Practically speaking, it is legitimate to enforce compliance with the former, since it is "objective and universally binding." ${ }^{20}$ The latter, however must remain the domain of personal volition, because enforcement would vitiate religious conviction. ${ }^{21}$ Interpersonal relations, in turn, are the building blocks of the "institutions and culture" that promote the common good. ${ }^{22}$ "The vision of intercommunal relations in Islam,"

\footnotetext{
${ }^{16}$ Sachedina, “The Role of Islam in the Public Square,” 181.

${ }^{17}$ Sachedina, The Islamic Roots of Democratic Pluralism, 34.

${ }^{18}$ Ibid., 20. Abduh and Rida maintained that "human responsibility to God is proportionate to the level of one's exposure through reason or revelation to God's purpose.”

${ }^{19}$ Sachedina, "The Role of Islam in the Public Square,” 175. See also Sachedina, “Jews, Christians, and Muslims According to the Qur'an,” Greek Orthodox Theological Review, Vol. 31, Num. 1

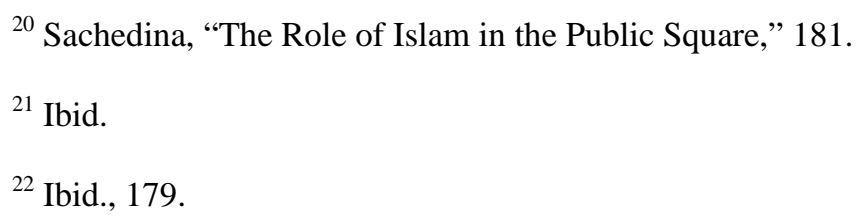
(1986): 109-111. 
Sachedina writes, “is firmly founded upon the diverse communities' sharing in cross-religious moral concern.”23 It is in the ethical realm that Islam "allows the other to be.”24

Religious freedom is based on recognizing the members of divergent faith communities as "spiritual equals" who can partner together to articulate moral values in the public square. As Sachedina writes, "How can a religious community remain neutral and non-interventionist on ethical issues that from the individual's point of view, might run counter to one's sense of the highest end in life?”25 This question poses difficulties for Islam in particular, which has always understood itself as a "public project."26

The answer is not secularism. Sachedina pointedly notes the failure of "secularly based imported ideologies” in Iraq to advance "pluralistic, tolerant political culture.”27 Secularism would deny religion entry into the public square, despite the fact that "the religious and ethic dimensions of personal life inevitably introduces religious precepts into the public arena”

${ }^{23}$ Ibid., 176. In The Islamic Roots of Democratic Pluralism, Sachedina footnotes this idea with Hans Kung’s "global ethic."

${ }^{24}$ Ibid., 175.

${ }^{25}$ Ibid., 179.

${ }^{26}$ Ibid., 174.

${ }^{27}$ Ibid., 178. It is interesting that Iraq alone generates this criticism. 
emphasis added). ${ }^{28}$ Moreover, secularism can lead to the demise of the "critical” role of religion in shaping the public conscience. ${ }^{29}$

To answer it, Sachedina turns to Sharia. He affirms Sharia as part of the legacy of Islam, one of the "religious-moral institutions" through which Muslims have shaped their community's ethical aspirations, but notes several problems in this legal heritage. ${ }^{30}$ Muslim jurists for centuries institutionalized the inferiority of non-Muslims as necessary for the public order. Subsequently, as a result of these "politically motivated legal decisions,” the Quranic spirit of freedom of conscience was violated. ${ }^{31}$

Sachedina unambiguously declares that certain juridical decisions regarding interreligious relations have become irrelevant, and he criticizes those who would "mechanically apply” historically conditioned rulings to modern situations. Sachedina sees jurisprudence monopolized by “exclusivists” who believe in an immutable law of God "blind to the interplay of

${ }^{28}$ Ibid., 180. Richard W. Garnett in “Freedom for Faith, Freedom for All,” First Things (December 2009) portrays what might be considered a Christian equivalent to Sachedina’s theory, articulated by Judge Janice Rogers Brown, a federal judge sitting on the United States Court of Appeals. Brown questioned the "sharp divide" between private and public life: "the internal spiritual life of [believers] and institutions must always move outward as a sign and instrument for the transformation of the larger society.”

${ }^{29}$ Ibid. Sachedina is actually making a much larger point here, i.e., that religion, and Islam specifically, may actually be critical to the survival of liberal democracy: "Islam provides the sole coherent worldview of any political significance, and consequently it serves as the only vital external perspective on the modern project of a secular world order. It is, probably, the only thoroughly religious critique of the international public order with its secularist and liberal presuppositions...[Islam] stands out as the only monotheistic tradition that can help deepen the West's self-understanding in its liberal project of a public international order." As noted by Andrew J. Bacevich, "Review of The Islamic Roots of Democratic Pluralism,” First Things, (April 2002): 55.

${ }^{30}$ Sachedina, “The Role of Islam in the Public Square,” 179, 185.

${ }^{31}$ Abdulaziz Sachedina, "Civic Responsibility in Political Society: An Islamic Paradigm,” in Taking Responsibility: Comparative Perspectives, ed. Winston Davis (Charlottesville, VA: University Press of Virginia, 2001), 249. 
culture, history, and faith. He calls for “conscientious, intelligent Muslims” to “decode” the corpus of Sharia through a "creative re-appropriation” of the juridical sources.

In his own interpretation Sachedina proposes a "functional secularity" facilitated by the Sharia's paradigm of separate jurisdictions. Sharia provides two distinct jurisdictions into which all laws can be divided. The first part deals with God-human relations, and covers all the laws relating to ibadat, or religious duties incumbent on all Muslims. ${ }^{32}$ Sacred immutability holds sway here. The second part addresses human-human relations, and covers all the laws and regulations concerning mu'amalat—“social transactions...between individuals and groups, including the state.”33 Importantly, this part of the law is not immutable, as it would periodically require reforms to deal with evolving social issues. It is worth quoting Sachedina in full here:

This separation of jurisdictions is the closest the Sharia can come to the secularism adopted in the western constitutions. It...can generate civic equality and mutual responsibilities at the human-human level of relationship, while maintaining the particularity and independence of the religious tradition from state administration. ${ }^{34}$

He then takes apostasy as a case study to prove the nuances this system could provide.

Historically, apostasy, although clearly in the realm of ibadat, was also considered under the rules for mu'amalat. Muslim jurists considered apostasy a source of instability to the public order. In keeping with their charge as God's vice-regent to keep the public order, Muslim rulers exercised jurisdiction over apostasy, which ranked with other civil crimes such as theft, armed robbery, wine-drinking, slander, and illicit sexual relations. They could therefore punish

32 "Ibadah," in The Oxford Dictionary of Islam, ed. John L. Esposito, Oxford Islamic Studies Online, http://www.oxfordislamicstudies.com/article/opr/t125/e911 (accessed 05-Nov-2009). Note the legal implications: "Because they are of central importance to the Muslim community, the ibadat form the first subject matter of Islamic jurisprudence and most collections of prophetic traditions (hadith).”

${ }^{33}$ Sachedina, “The Role of Islam in the Public Square,” 186.

${ }^{34}$ Ibid. 
apostates_ - and still can by Sachedina's reasoning — according to the threat posed to the unity and safety of the Islamic community. Yet the Quran lays down no temporal punishment for apostasy; thus, the "mere expression of religious dissent” would not constitute a criminal act, in keeping with the Quran's spirit of religious pluralism. ${ }^{35}$

\section{Philosophers}

The Islamic tradition of philosophy, in Arabic falsafa, stretches back to the first efforts of Muslim thinkers to interpret, both literally and metaphorically, the ancient Greek philosophical collections. Broadly speaking, falsafa emphasized the power of the human intellect to understand God and the world. Those who exercised reason in metaphysical pursuits had their counterparts who dwelt on social philosophy, with its end of improving social order. In turn, modern Muslims have combined this historical concern for social issues with modern Western social science methodology to create a burgeoning Islamic social science, i.e., the rigorous use of empirical evidence to study social effects conditioned by the Islamic religious system. ${ }^{36}$

M. A. Muqtedar Khan is one of the most prominent American Muslim voices today in this effort. Like many of his colleagues, he is concerned with implementing effective social reform in order to revitalize Muslim societies that he feels lag behind Western societies. ${ }^{37}$ Specifically, as an Islamic political scientist, he argues that Muslim societies can and should democratize, beginning with the democratization of intellectual structures through ijthihad.

\footnotetext{
${ }^{35}$ Sachedina, The Islamic Roots of Democratic Pluralism, 101. Cf. essays by Kadivar and Talbi in Mehran Kamrava, The New Voices of Islam: Rethinking Politics and Modernity (Berkeley: University of California Press, 2006).

${ }^{36}$ Syed Hussein Alatas and Jane H. Murphy, "Social Sciences," in The Oxford Dictionary of Islam, ed. John L. Esposito, Oxford Islamic Studies Online, http://www.oxfordislamicstudies.com/article/opr/t236e0749 (accessed Dec 14, 2009).

${ }^{37}$ Ibid.
} 
Khan emigrated to the United States from Hyderabad, India as a young man. He earned a Ph.D. in international relations at Georgetown University in 2000, has taught at Adrian College and the University of Delaware, where he is currently Assistant Professor in the Department of Political Science and International Relations. In addition to teaching, Khan has served as President, Vice President, and Secretary of the American Muslim Social Scientists (AMSS), managing editor of the American Journal of Islamic Social Sciences (AJISS), member of the Board of Directors for the Center for the Study of Islam and Democracy, and as non-resident fellow at the Brookings Institution.

He has written three major books and scores of articles on Islam and democracy, Islam in America, American foreign policy, and other topics, many of which can be found on his websites www.ijtihad.org and/or www.glocaleye.com. ${ }^{38}$ After 9/11, Khan took upon himself the role of a public intellectual for the American Muslim community, and has persistently argued that it has a special role to play in the development both of American society and those in the Muslim world. ${ }^{39}$ It is primarily his 2002 book American Muslims: Bridging Faith and Freedom and 2005 essay “The Politics, Theory, and Philosophy of Islamic Democratic Discourse” (in a published collection edited by himself), as well as various blogs and Web articles, that will be examined here. $^{40}$

${ }^{38}$ Self-reported biographical information obtained from http://www.ijtihad.org/ (accessed November 5, 2009).

${ }^{39}$ Charles Strohmer, “Change Agents,” The Christian Century, Vol. 122, Iss. 16 (2005): 24. See also Alatas and Murphy, "Social Sciences.”

${ }^{40}$ M.A. Muqtedar Khan, American Muslims: Bridging Faith and Freedom, 1st ed. (Beltsville, MD: Amana Publications, 2002); M.A. Muqtedar Khan, "The Politics, Theory, and Philosophy of Islamic Democracy," in Islamic Democratic Discourse: Theory, Debates, and Philosophical Perspectives, ed. M.A. Muqtedar Khan (Lanham, MD: Lexington Books, 2006). 
Like Sachedina, Khan affirms freedom of religion as a fundamental human right. He is suspicious of U.S. international religious freedom policy, claiming that its sole purpose is to identify and remove barriers to Christian missionary activity in the "heartlands" of Islam, ${ }^{41}$ but nonetheless he praises the United States as a place where Muslims can practice Islam "at the highest level” because of their political and religious freedoms. ${ }^{42}$ He states unambiguously his view that the Muslim world needs to create governments which "ensures that women and minorities are guaranteed, at the minimum, the basic human rights enshrined in international law. ${ }^{43}$ Yet the key to advancing minority rights is in political philosophy rather than theology or jurisprudence. Khan folds into his argument verses from the Qur'ran and certain precedents in Islamic history, but appeals to an epistemology of reason rather than revelation, modeling himself after Abdelkarim Sorroush. ${ }^{44}$ Khan thinks reason shows that democracy is compatible with Islam, which possesses democratic concepts that if only applied would lead to good governance. His position is clear: "Muslims must widely and unambiguously accept that Islam and democracy are compatible and that meaningful faith requires freedom.”45

\footnotetext{
${ }^{41}$ Khan, American Muslims,51.

${ }^{42}$ M.A. Muqtedar Khan, “America’s Gift,” Pittsburgh Post-Gazette, 25 March 2007.

${ }^{43}$ Khan, “The Politics, Theory, and Philosophy of Islamic Democracy,” 155.

${ }^{44}$ Khan, The Politics, Theory and Philosophy of Islamic Democracy,165-166. See also Abd alKarim Surush, Mahmoud Sadri and Ahmad Sadri, Reason, Freedom, \& Democracy in Islam : Essential writings of 'Abdolkarim Aoroush (New York, NY: Oxford University Press, 2000). Soroush calls reason a "collective participation" of human thought across history. Democracy is the best way to ensure such participation, because it ensures freedom of thought, and freedom is necessary to pursue ijtihad, i.e., employ reason in comprehending and communicating the ideals of religion. Religion provides the standards - reason comprehends and applies the standards (to our times) - freedom encourages reasondemocracy safeguards freedom-the Creator's approval is secured (Reason, Freedom, \& Democracy in

${ }^{45}$ Khan, "The Politics, Theory and Philosophy of Islamic Democracy, 155.
} Islam,127-128). 
Khan begins with the idea of an Islamic religious state. After analyzing contemporary Islamist theory behind an Islamic state, he concludes that a truly Islamic state would a) be thoroughly democratic; and, b) have robust rights for religious minorities. His conclusions intentionally counter a key tenet of contemporary Islamist theory: that sovereignty belongs to God alone (espoused most formidably by the twentieth century Pakistani ideologue Sayyid Abu al-A'la Mawdudi ). ${ }^{46}$ According to this view, it is the application of God's law, Sharia, that makes a polity legitimate. Furthermore, because God has decreed it, Sharia cannot be negotiated by any democratic process, which would render divine decrees subject to human whim. ${ }^{47}$

Khan attacks this idea and argues that human sovereignty is a reality whether the state is religious or not. The question is not whether humans are sovereign but what are the best processes to hold human sovereignty accountable. Interestingly, he does incorporate part of Mawdudi's theory into this own, namely that the general population does possess a certain amount of sovereignty as "vice-regents"; but Khan departs from Mawdudi where the latter splits this “vice-regency" with the Caliphate, which Khan discards as an outdated institution. ${ }^{48}$

Human sovereignty is thus located exclusively in the population. Citizens thus need freedom in order to learn and choose virtue. ${ }^{49}$ A democratic system can provide that freedomincluding the freedom to authentically live out one's faith. So the sequence for Khan is to

\footnotetext{
${ }^{46}$ Seyyed Vali Reza Nasr, "Mawdūdī, Sayyid Abū al-A'lā," in The Oxford Encyclopedia of the Islamic World, ed. John L. Esposito, Oxford Islamic Studies Online, http://www.oxfordislamicstudies.com/article/opr/t236/e0517 (accessed 29-Mar-2010).

${ }^{47}$ Khan, American Muslims,109-111.

${ }^{48}$ Ibid., 111.

${ }^{49}$ Khan, "The Politics, Theory and Philosophy of Islamic Democracy,” 165. He draws this idea from the medieval Muslim philosopher Al-Farabi.
} 
democratize first, and incorporate religion into the debate about laws, governance, and morality later.

Like Sachedina, Khan takes care to de-link democracy and secularism: "secularism is a liberal tradition not a pre-requisite for democracy." ${ }^{50}$ In contrast, he sees religion as an important source of "good citizens" and "good laws"- the two ingredients for good governance. ${ }^{51}$ Moreover, a democratic polity that truly accords with Islamic principles will necessarily promote and protect religious pluralism. To prove this point, Khan appeals to the Compact of Medina, an important text from very early Islamic history that established Muslim society in Medina following the forced hijra (emigration) from Mecca. ${ }^{52}$ According to Khan, this document provides Muslims with an example from their tradition of two theoretical constructs that have influenced contemporary political thought: a) the social compact; and, b) the constitution. The Compact of Medina thus set two important precedents for Muslims in modern times: a) the implementation of “divine law” based on consultation and consent of all citizens; and, b) internal autonomy for religiously-organized communities. ${ }^{53}$

Both points are important to Khan. The first rules out arbitrary articulation and enforcement of religiously based law, i.e., Sharia. Laws must be “democratically negotiated conclusions” that enjoy the consent of all citizens, including minorities. The second point provides a foundation for religious pluralism. By permitting religious communities to live under

${ }^{50}$ Khan, American Muslims,96.

${ }^{51}$ Ibid., 114.

${ }^{52}$ Awad Halabi, “Constitution of Medina,” in The Oxford Dictionary of Islam, ed. John L. Esposito, Oxford Islamic Studies Online, http://www.oxfordislamicstudies.com/article/opr/t236/e1003 (accessed 05-Nov-2009).

${ }^{53}$ Khan, American Muslims,102. 
their own religious legal system, Islamic tradition actually goes beyond modern Western ideas of religious freedom. ${ }^{54}$

The great obstacle to realizing this vision is the "fossilized" system of Sharia with its elitist jurists. Khan pulls no punches here. Jurists have “colonized” Islamic thought and reduced it to the status of a medieval legal tradition. ${ }^{55}$ Their "intellectual arrogance” betrays their entrenched interest in preserving their authority to interpret Islamic law. ${ }^{56}$ They are suspicious of any kind of democracy that could entail “democratic negotiations” over governance, religion or Sharia. ${ }^{57}$ Even American Muslim jurists are guilty of these attitudes. In what has become a public spat, Khan charged Abou El Fadl with allowing his juridical background to "subvert his quest for an Islamic democracy.” 58

The answer is to foster ijtihad, or independent thinking, and "democratize interpretation." ${ }^{59}$ The resultant multiplicity of interpretations would be tested by mutual consultation, shura, among Muslims, and even non-Muslims: "Islam belongs to all of us...it’s not that Muslims own Islam.”60 Khan justifies this generous orthodoxy by essentializing ijtihad

\footnotetext{
${ }^{54}$ Ibid., 102-104.

${ }^{55}$ Khan, “The Politics, Theory and Philosophy of Islamic Democracy,”159.

${ }^{56}$ Ibid., 163.

${ }^{57}$ Ibid., 161.
}

${ }^{58}$ M.A. Muqtedar Khan, “The Primacy of Political Philosophy,” in Islam and the Challenge of Democracy, eds. Joshua Cohen, Deborah Chasman and Khalid Abou El Fadl (Princeton, NJ: Princeton University Press, 2004); David Glenn, “Who Owns Islamic Law?” The Chronicle of Higher Education, February 2005.

${ }^{59}$ Khan, “The Politics, Theory and Philosophy of Islamic Democracy,”161.

${ }^{60}$ Glenn, “Who Owns Islamic Law?”. 
as “part of what makes [one] human.”61 Yet Khan does not equate ijtihad or shura with democracy, much less liberal democracy; the point here is that his approach dramatically rewrites the traditional role of the jurists. Only by opening up interpretation can Islamic thought escape the "colonialism" of the jurists that perpetuates "fossilized" Islamic legal and political practices. Jurists

The term jurist is the English equivalent for the Arabic faqih, meaning a Muslim trained in the great Islamic system of law known as Sharia. In western discourse Sharia is often shorthand for a corpus of statutes religious in nature and medieval in character. Yet in traditional Islamic discourse Sharia has assumed far grander definitions: it is "the divine law...the straight path...the command of God for mankind." Sharia is understood to transcend human institutions, while fiqh is the study of the law as a human activity; one who is trained in fiqh is a faqih. The science of fiqh, or jurisprudence, has produced such a voluminous body of literature and required such rigorous study that its students have garnered tremendous esteem throughout the centuries. ${ }^{62}$

Khaled Abou El Fadl is an American faqih. ${ }^{63}$ Born in 1963 in Kuwait, he earned the honorific title "hafiz” at age twelve by memorizing the Quran. As a young man he undertook 13 years of classical training in Islamic jurisprudence in Kuwait and Egypt, where he suffered imprisonment and torture by the government. ${ }^{64}$ He emigrated to the United States in 1982 and received his B.A. in political science from Yale University, his J.D. from the University of

${ }^{61}$ Ibid.

${ }^{62}$ Skreslet, 77-78.

${ }^{63}$ This term is used in reference to his classical training, not his past or present role in any Islamic law-formulating body in the United States, such as the Fiqh Council of North America. 2008).

${ }^{64}$ Paul Barrett, American Islam: The Struggle for the Soul of a Religion (New York: Picador, 
Pennsylvania, and an M.A. and Ph.D. in Islamic studies from Princeton University. El Fadl currently serves as Distinguished Professor of Islamic Law at the University of California-Los Angeles School of Law.

El Fadl has lectured and published widely on Islamic law, Islam and democracy, and issues pertaining to pluralism, tolerance, and human rights in Islam. He is a member of editorial or advisory boards for numerous journals dedicated to these topics including the Journal of Religious Ethics, the Journal of Islamic Law and Society, and the Harvard Press Series on Islamic Law. Throughout his career he has targeted Wahhabi ideology as a misguided expression of Islam and has publicly criticized several official fatwas, or edicts, issued by Saudi Arabia’s legal body. In 2003 President George W. Bush appointed him as a Commissioner for the United States Commission on International Religious Freedom, where he served until 2007. Three of his writings are examined here: the books Tolerance in Islam and Islam and the Challenge of Democracy and the essay“ Between the Unique and the International,” a study of international law; several other essays will be referenced occasionally.

El Fadl's views on religious freedom begin and end with Sharia, which he sees as essentially concerned with human welfare. ${ }^{65}$ Importantly, El Fadl insists on the transcendence of Sharia from human thought, and thus human error; at the same time, however, he argues that human understanding of Sharia is imperfect and contingent. ${ }^{66}$ Islamic law has always been an "authorial enterprise” that reflects "power dynamics and social biases” as it is constructed

${ }^{65}$ Aziz Huq, “Khaled Abou El Fadl,” in Encyclopedia of Islam in the United States, ed. Jocelyne Cesari (Westport, CT: Greenwood Press, 2007), 6-7.

${ }^{66}$ Khaled Abou El Fadl and Joshua Cohen, Islam and the Challenge of Democracy, (Princeton, NJ: Princeton University Press, 2004), 33. 
through a "sociology of process." ${ }^{, 67}$ The end result is the possibility of reforming certain laws that reflect a particular historical bias while respecting the process of interpreting religious law. ${ }^{68}$ Sharia, then, is a process, a striving, not a set of rules.

El Fadl appeals directly to the Quran to make the case for tolerance within Islam. He argues that the Quran accepts the reality of diversity in the world and moreover asserts that diversity is part of the divine intent and purpose in creation. ${ }^{69}$ This principle was not seriously developed in Islamic theology due to a "political dominance... which engendered self-sufficient confidence” among early Muslim theologians. Nonetheless, El Fadl maintains, Islamic civilization showed a relatively high level of tolerance.

Following on diversity, the Quran endorsed pluralism. It accepted the existence of multiple religious beliefs and laws, as evidenced through its universalist soteriology and call for reciprocity with Jews and Christians. For El Fadl, the existence of these principles in the Quran means ramifications for Islamic law:

The Quranic celebration and sanctification of human diversity incorporates that diversity into the purposeful pursuit of justice and creates various possibilities for a pluralistic commitment in modern Islam. That commitment could be developed into an ethic that respects dissent and honors the right of human beings to be different, including the right to adhere to different religious or non-religious convictions. At the political level it could be appropriated into a normative stance that considers justice and diversity as core values that a democratic constitutional order is bound to protect. $^{70}$

${ }^{67}$ Khaled Abou El Fadl, “The Unique and International and the Imperative of Discourse,” Chicago Journal of International Law 8, Num.1 (2007): 50.

${ }^{68}$ El Fadl and Cohen, 35.

${ }^{69}$ Khaled Abou El Fadl and Joshua Cohen, The Place of Tolerance in Islam, (Boston: Beacon Press, 2002), 15-16.

${ }^{70} \mathrm{El} \mathrm{Fadl} \mathrm{and} \mathrm{Cohen,} \mathrm{Islam} \mathrm{and} \mathrm{the} \mathrm{Challenge} \mathrm{of} \mathrm{Democracy,} 35$. 
In addition to the Quran, El Fadl cites two famous Muslim jurists, al-Mawardi and Ibn Abi alRabi', and their juristic argument for the necessity of diversity and cooperation in the realization of justice. ${ }^{71}$

The key question for El Fadl, and the category he represents, is how to define justice. He insists that it does not simply follow from knowing what the divine law requires. Rather, understanding what justice requires come prior to interpreting the divine law—“a serious paradigm shift in Islamic thinking.” And understanding justice means being guided by mercy, which requires "genuine perception of the other" and not mere co-existence. ${ }^{72}$

One crucial extension of justice is the possession of rights. Islamic jurisprudence contains precedent for individual rights, albeit not to the degree of Western legal thought. The reason for this, El Fadl suggests, is that Muslim jurists focused on “justiciable situations” rather than broad theoretical categories:

[T]he jurists tended to focus on tangible property rights or rights for compensation instead of moral claims...Despite this limitation, the juristic tradition did, in fact, develop a notion of individual claims that are immune from governmental or social limitation or alienation. ${ }^{73}$

El Fadl implies that another paradigm shift is required to extend this precedent into the principle of rights as property regardless of legal cause for action. ${ }^{74}$ Drawing on another established principle in Islamic law, he clarifies that violations of God's rights (huquq Allah) are not cause for action-in other words, "the claimed right of God may not be used to violate the rights of

\footnotetext{
${ }^{71}$ Ibid., 19.

${ }^{72}$ Ibid., 21-22.

${ }^{73}$ Ibid., 27.

${ }^{74}$ Ibid., 27.
} 
human beings.”75 God will vindicate His rights in the Hereafter; humans need to be concerned with defending the rights of their fellow human beings. Finally, El Fadl claims that the Quran does not differentiate between the sanctity of a Muslim and a non-Muslim, and thus by extension, neither should Islamic law. ${ }^{76}$

If Sharia thus can service and promote diversity, pluralism, and individual rightsincluding the right of conscience and belief - the key question turns on ownership of interpretation. The strategic thrust of El Fadl's thought here has the twin aims of preserving the (moral) authority of the jurists while advancing democratization. His tactical approach is to distinguish between religious laws and state laws. He preserves the claim of the jurists to act as interpreters of Sharia (imperfectly), while the people-through the vehicle of a democratic government - exercise their moral agency by deciding whether to make the jurists' interpretations the laws of the state. The ulama, as "moral educators," have a special role to play as "curators who point the nation toward the ideal that is God," yet remain independent of the state, which cannot enforce religious laws—only human laws. “A code, even if inspired by Sharia, is not Sharia."77

El Fadl also argues that Sharia potentially can contribute to international law. He bases this on the ideas that a) the legitimacy of international law rests on consent theory ${ }^{78}$; and, b) Islam's claim to universality requires it to take other universal claims seriously. ${ }^{79}$ For

\footnotetext{
${ }^{75}$ Ibid., 28.

${ }^{76}$ Ibid., 29.

${ }^{77}$ Ibid., 36.

${ }^{78}$ Ibid., 45.

${ }^{79} \mathrm{El} \mathrm{Fadl}$, “The Unique and International and the Imperative of Discourse,” 52.
} 
international law to be both relevant and legitimate requires the consent of the "actual international collectivity" — human beings—and thus must necessarily engage with "religious determinations.” Likewise, for Muslims to ignore the “international audience,” which may consent to international law and a human rights regime, is to "de-legitimize the universalism of Islam." ${ }^{80}$ Careful, honest discourse between the "unique and the international” holds promise for arriving at a "collaborative” institution that safeguards the "sublime qualities" of all that is human. $^{81}$

\section{Reflection on Sachedina}

Sachedina tries to build parity among different religions by appealing to universal morality. ${ }^{82}$ Sachedina uses it to create common ground for action in the name of ethics; religious and non-religious actors could presumably cooperate in fulfilling the ethical prescriptions that flow from this universal morality. But this assumes that these actors would agree in the articulation of such prescriptions. This is the same assumption made by Ismail al-Faruqi, a pioneering American Muslim intellectual, who argued that the need to realize the will of God in human responsibility and accountability transcended differences within the Muslim umma and even between religions. However, as Islamic scholars John Esposito and John Voll point out, behind this broad minded ethic was an assumption that "believers would more or less agree on

\section{${ }^{80}$ Ibid.}

${ }^{81}$ Ibid., 57.

${ }^{82}$ This is common in American Muslim discourse, e.g. Feisal Abdul Rauf, a prominent American Muslim imam states: "Islam's natural impulse is a globalized religion based on a set of universal principles that all of humanity can agree on." In What's Right with Islam : A New Vision for Muslims and the West, 1st ed. (San Francisco: Harper, 2004). 
divinely revealed ethical principles”—even though important differences existed between religious traditions on matters such as alcohol, sexual propriety, and so on. ${ }^{83}$

In methodology, Sachedina typifies the modern Islamic theological approach, which challenges the "jurocentric hermeneutic" exemplified in part by El Fadl. ${ }^{84}$ Sachedina takes care to appeal to exegetes, but he bases his theory on a direct, personal interpretation of the Quran. Without saying as such, he claims the right to exercise ijthihad, appealing to the example of Sayyid Qutb (and Tantabata’i). Yet ijtihad is hotly contested in the Muslim intellectual atmosphere, no less so among American Muslims, with sharp disagreements over who is qualified to exercise ijtihad, what the methods are, and what the goal should be. ${ }^{85}$ Thus Sachedina's interpretations could be palatable only to those who likewise favor "democratic" ijtihad. ${ }^{86}$ Ironically, this would figures like Qutb and Mawdudi, major contributors to the Islamist project of the last century, but who were not classically trained themselves.

A theological approach does yield a more persuasive "religious” argument, which perhaps better prepares the public consciousness for religious pluralism. Theological pluralism that contains an inherent tolerance for other faiths may well be the vehicle with which to drive changes in widespread popular understandings of religious freedom. ${ }^{87}$ Yet while Sachedina

${ }^{83}$ Esposito and Voll, Makers of Contemporary Islam, 35.

${ }^{84}$ Ebrahim Moosa, review of The Islamic Roots of Democratic Pluralism, by Abdulaziz Sachedina, The Journal of Religion, Vol. 85, Iss. 1 (Jan 2005): 172-173.

${ }^{85}$ David Smock, “Ijtihad: Reinterpreting Islamic Principles for the Twenty-first Century,” United States Institute of Peace Special Report 125 (Washington, DC: USIP, 2004); Glenn, "Who Owns Islamic Law?”.

${ }^{86}$ For example, Muqtedar Khan.

${ }^{87}$ Cf. John Esposito, "State Department's religious freedom report shows global need for interfaith tolerance,” Jurist, 30 Nov 2009, available at http://jurist.law.pitt.edu/hotline/2009/11/statedepartments-religious-freedom.php. 
argues eloquently for the inherent dignity of all humans as spiritual equals, there remain gaps between freedom of conscience and the political order.

First, although Sachedina’s arguments can definitely be read as comprehensive of all religious faiths, it does not account for people of no faith? Muslim theological and legal thought remains weak on the categories of atheists and agnostics, and Sachedina does nothing to effect the contrary. His generous orthodox stays confined to the traditional "other” in Muslim discourse, i.e., Christians and Jews. ${ }^{88}$

Second, while Sachedina's work provides good resources for religious pluralism, it does not bridge the distance to political pluralism. His denunciation of secularism seems to already exclude those who disagree with a role for religion in the public square. To borrow a phrase from political scientist Amy Gutmann, citizens in Sachedina’s public square are morally responsible for reciprocity, but it is not clear whether they are empowered to justify their actions according to a non-religious theory of cooperation and justice. ${ }^{89}$ As Khan points out, one is thus left to wonder whether an Islamic state consistent with Sachedina's vision would allow for competing political ideologies, such as communism. ${ }^{90}$

Third, Sachedina's counterproposal of "functional secularity" is problematic in that it provides only “one-way protection”, i.e., it protects the religious tradition from the state, but not the state from religion. ${ }^{91}$ Scholar and political scientist Daniel Philpott has argued that states can

${ }^{88}$ Nader Hashemi, “Inching Towards Democracy: Religion and Politics in the Muslim World,” Third World Quarterly, Vol. 24, Num. 3 (2003): 573-574.

${ }^{89}$ Amy Gutmann, “Religious Freedom and Civic Responsibility,” in Taking Responsibility: Comparative Perspectives, ed. Winston Davis (Charlottesville: University Press of Virginia, 2001), 47-48.

${ }^{90}$ Khan, “The Politics, Theory and Philosophy of Islamic Democracy,” 158.

${ }^{91}$ Gutmann, 47-48 and 54-57. 
be cross-ranked according to the degree of legal, constitutional separation between religion and state, and whether that separation is consensual or conflictual. Using this schema, Sachedina's model at best results in a high consensual, low differentiation regime like Saudi Arabia or Sri Lanka, in which "the state and the dominant religious community collaborate closely and share prerogatives." ${ }^{92}$

\section{Reflection on Khan}

Khan is focused on democracy, not religious pluralism or religious freedom per se. His preferred method would be to democratize first, creating space for progressive reformers, who could then challenge traditional restrictions on the freedom of conscience and belief. Like Sachedina, he justifies his argument through direct appeals to the Qur'an, but unlike the former he makes heavy use of both Islamic and Western political theory.

He assumes that democracy (at least a truly Islamic democracy) necessarily leads to popular acceptance of religious freedom. While this sequence has been born out in recent history, for example in the "third wave" of democratization, it admits of several degrees, not all equating to immediate and/or comprehensive freedom of religion for minorities-as is the case currently in Pakistan, Indonesia, and Iran. ${ }^{93}$ Even where participatory representation becomes the rule, simple majority tyranny could vitiate the free practice of religious minorities. As Abou El Fadl points out, even shura must be measured against a fixed system of private and individual rights. ${ }^{94}$

92 Daniel Philpott, "In Search of the Twin Tolerations,” The Review of Faith \& International Affairs, ed. Dennis Hoover and guest editor Thomas Farr, Vol. 6, Num. 2 (Summer 2008): 9-12.

${ }^{93}$ Cf. Daniel Philpott's remarks in Berkley Center for Religion, Peace \& World Affairs, Report of the Georgetown Symposia on U.S. International Religious Freedom Policy (Washington, DC: Georgetown University, 2008): 20.

${ }^{94}$ Glenn, “Who Owns Islamic Law?”. 
Khan also fails to account for countries that may never become democracies, offering no suggestions for the advancement of reform in such cases.

Perhaps the most serious problem in Khan's presentation is his implication that the standard of religious freedom is communal autonomy. This runs counter to liberal political theory, which fixes the rights of the individual as paramount. Here Khan is standing firmly on Islamic precedent, which includes the Constitution of Medina and various later codifications of dhimmi status, including the Ottoman millet system in which Christians, Jews, and other groups organized their religious affairs internally. Yet Sachedina, in his discussion of the millet system, notes two linked problems with this precedent: a) it entails some degree of state control over religious identification; and, b) by putting the enforcement of religious orthodoxy under state patronage, no room was left for individual dissent—-"every episode of the individual exercise of freedom of conscience was seen as a deviation from the accepted orthodoxy maintained and enforced by the socio-religious order." ${ }^{95}$ From the opposite angle, individual members of autonomous religious communities could potentially be denied access to the state and its institutions. $^{96}$

Nonetheless, Khan's attention to religious freedom is promising, if only because he represents—and agitates on behalf of—-social science in the Muslim world. As a serious academic discipline built on rigorous empirical evidence, social science may help ground the

95 Sachedina, “The Role of Islam in the Public Square,” 182.

${ }^{96}$ Cf. Zeyno Baran, U.S. Congress, Hearing of the Senate Committee on Foreign Relations, "Engaging With Muslim Communities Around the World,” (February 26, 2009), http://www.gpo.gov/fdsys/pkg/CHRG-111shrg60/pdf/CHRG-111shrg60.pdf (accessed February 26, 2009)Baran questioned the compatibility of Sharia with American civil law, and whether those under Sharia in a dual-law system would have access to non-religious courts. Moreover, she questioned whether support for such a scenario was really widespread: “Ask Muslim women if they really want Sharia courts.” Available at http://foreign.senate.gov/hearings/2009/hrg090226p.html 
case for religious freedom to Muslim audiences_-including elites who can initiate top-down reform. Syed Hussein Alatas (b.1928) writes that ideally conceived, Islamic social science "must have an empirical, descriptive basis in contemporary realities and cannot be only idealizations of what Islamic society ought to be, or accounts of earlier periods of Islamic history which are taken to be exemplary with no changes made to reflect modern realities. ${ }^{\text {,97 }}$ In his discussion on religious freedom, Khan unfortunately proves a deviant in some ways to Alatas’s dream vis-à-vis his reference the Constitution of Medina and its organization of communal religious autonomy; ultimately, however, he or other American Muslim social scientists/social philosophers may be well-positioned to marry the burgeoning socio-economic evidence for religious freedom with their (self-assigned) campaign to reshape Muslim communities. ${ }^{98}$

\section{Reflections on El Fadl}

El Fadl's comprehensive treatment of Sharia is valuable first and foremost for addressing the most pressing issue in the debate over democracy, human rights, and religious freedom in the Muslim world. El Fadl contributes to the debate by going beyond the usual dichotomy between “apologists” and "puritans” by appealing to the best intentions of Sharia while noting the “failures of process” in its formation.

Much depends on his definition of justice, to which he makes Sharia subordinate. It follows that any formulation of Islamic law would need to adhere to this definition of justice. However, as Mohammad Fadel has noted, in Islam justice has always followed revelation. ${ }^{99}$ This

${ }^{97}$ Alatas, Syed Hussein and Jane H. Murphy, “Social Sciences.”

${ }^{98}$ Brian Grim, “Is Religious Freedom Good for Us?” The Review of Faith \& International Affairs, ed. Dennis Hoover and guest editor Thomas Farr, Vol. 6, Num. 2 (Summer 2008): 3-7.

99 Mohammad Fadel, “Too Far From Tradition,” in Islam and the Challenge of Democracy, eds. Khaled Abou El Fadl and Joshua Cohen (Princeton, N.J.: Princeton University Press, 2004), 82. 
is an important distinction. Much Western jurisprudence is founded on principles derived from natural law; in contrast, moral law serves as the foundation for Islamic jurisprudence. From a Muslim perspective, the two are not synonymous. Natural law is supposed to be "self-evident" in creation/nature whereas moral law is always expressed as revelation(s) via the prophets, with the culmination of revelation being the text of the Qu'ran. Moral law then becomes a matter of textual analysis, and its study equivalent to a science (fiqh), whereas natural law continually seeks philosophical "first principles” to justify itself. For El Fadl to even begin to suggest that justice follows conception, rather than revelation, is radical.

In fact, though, El Fadl never explicitly defines justice, aside from calling for the principle of mercy. Instead he provides potentialities, such as the principle of individual rights, which conceivably extend the principle of justice but do not fulfill it. Bernard Haykel identifies this gap, pointing out that El Fadl's work, while providing an important analysis of the moral compatibility between Islam and democracy, lacks the "actual processes and mechanisms, both legal and extra-legal” which could bring about an Islamic democracy. ${ }^{100}$

Undoubtedly El Fadl's agenda is to preserve and promote Sharia and fiqh as relevant and valued Islamic institutions, "without having to sacrifice either the appearance or substance of authenticity.” ${ }^{101}$ He takes care to delineate the role Sharia could play in a democratic state, going further than Sachedina's "separate jurisdiction” theory by ultimately investing the people alone, through the state, to create law. Likewise, the ulama remain, but only as "moral educators.” But one wonders just where the line is drawn for these “custodians...and curators.” There is no

${ }^{100}$ Bernard Haykel, “Popular Support First,” in Islam and the Challenge of Democracy, eds. Khaled Abou El Fadl and Joshua Cohen (Princeton, N.J.: Princeton University Press, 2004), 78.

${ }^{101}$ Khaled Abou El Fadl, “The Human Rights Commitment in Modern Islam,” in Human Rights and Responsibilities in the World Religions, eds. Joseph Runzo, Nancy M. Martin, and Arvind Sharma (Oxford: Oneworld, 2003), 304. 
insistence that they never come into political power; and what happens if they do? More curious still is the apparent contradiction between his call for the "democratization" of international law and his bent toward reserving the interpretation of Sharia to a juridical corps. If, as he argues, both international law and Sharia have experienced a "failure of process" by excluding certain voices (i.e., women), would not the solution for both be similar if not the same? El Fadl does not make this connection, yet without a clear endorsement of the inclusion of women and minorities in the consideration and articulation of fiqh, their legal status could continue to improve at a very slow pace.

\section{Conclusion}

This chapter began by asking about the possibility for a "coherent theoretical stand" on which American Muslims can promote international religious freedom. The works of these three American Muslim intellectuals demonstrates that such a possibility exists, with the following key planks: a) a contextual interpretation of core Islamic sources; b) a critical but broad acceptance of Western political and economic theory, including an argument for democracy; and, c) a rejection of rigid secularity.

First, they appeal to the foundational sources of Islamic tradition, i.e., the Quran, and the great legal science that undergirds Sharia. ${ }^{102}$ The Quran figures prominently into their writing, and indeed must serve as the base for any conceptualization of Islamic religious or political theory. Sharia is likewise considered, most comprehensively by El Fad, and most dramatically by Khan. Despite the stark contrast between these two on Sharia, they both, with Sachedina, insist that the Quran, Sunnah, and Sharia (or fiqh) must be read in the context of seventh-century Arabia, and consequently, reinterpreted to move past problematic provisions or principles no

${ }^{102}$ Interestingly, only Khan appeals to the Sunnah, easily the most important source for Islamic practice after the Quran. 
longer sensible in modern times. This approach, known in Arabic as tafsir bil-ra $\dot{y}$, follows in the line of rationalist methods first established by the Mu'tazilite school in the eleventh-century. Yet this approach has long been overshadowed by the more literalist approach known as tafsir bial ma thūr. As Islamic scholar Peter Riddell notes, the latter has always enjoyed more widespread subscription both in the past and today. ${ }^{103}$ The point here is that their approach places Sachedina, Khan, and Abou El Fadl squarely in the "modern rationalist” camp of Islamic intellectual thought, which is historically and currently a minority in the broader Muslim world.

At the same time, their Islam borrows from western political theory. In his writing, Sachedina assumes that the concepts of pluralism and democracy enjoy wide consensus, without questioning this assumption. ${ }^{104}$ Nor does he take up the question of how the "master narratives" of globalization or capitalism might mediate the theology he advocates. ${ }^{105}$ Similarly, Khan largely accepts a global capitalist economy, ${ }^{106}$ and borrows heavily from Western political constructs in his argument for direct popular sovereignty, even (and perhaps especially) on explicitly religious issues where religious authority has traditionally decided the question. El Fadl likewise imports Western political and legal ideas into his arguments, although he does critically question them beforehand.

Explicit in their writings is an argument for democracy, albeit qualified according to their theological, political, or legal frameworks. One of the key questions raised in this democratic

${ }^{103}$ Peter Riddell, "Exegesis," in The Oxford Encyclopedia of the Islamic World, ed. John L. Esposito, Oxford Islamic Studies Online, http://www.oxfordislamicstudies.com/article/opr/t236/e0227 (accessed 05-Nov-2009).

${ }^{104}$ Khan, “The Politics, Theory and Philosophy of Islamic Democracy,” 156.

${ }^{105}$ Moosa, 172-173.

${ }^{106}$ Alatas and Murphy, "Social Sciences.” 
discourse is over sovereignty. Who gets to decide? And what happens if those decisions are counter to the revealed and/or interpreted divine will? Both Khan and El Fadl labor to refute the popular rhetorical argument against sovereignty of the people spawned by the works of Mawdudi and others, and they both agree with Sachedina in preserving the right of the people to choose their laws. But, while Khan says that even Sharia should be a popular sovereignty issue, El Fadl maintains that a juridical corps alone can be entrusted for interpretation. Sachedina leans toward Khan, criticizing narrow conceptions which have "monopolized” Sharia, and calling on “intelligent, conscientious Muslims” to reinterpret it (i.e., not just jurists). Yet all three would strongly agree with Islamic scholar Asma Afsaruddin’s urging for a “revival of religious learning and historical scholarship” among Muslims everywhere in order to put “obscurantism” to rest. Democratization of learning, if not interpretation, remains a key component of an American Muslim approach. ${ }^{107}$

Finally, their articulation of Islam rejects rigid secularism. All three hold that secularism per se is neither a model for Islamic democracy nor the only/best safeguard for human rights, including religious freedom. ${ }^{108}$ Their working definition of secularism is the absence of religious “reasons” in the public square-although, with the exception perhaps of El Fadl, their definition is too reductionist, not allowing for the range extant in modern liberal democracies The main point here is that all three make the make the argument for a religiously-motivated protection of religious freedom; they are not arguing for religious freedom based on secular principles, but

${ }^{107}$ Asma Afsaruddin, “Absolutism vs. Pluralism in Islam Today,” The Review of Faith \& International Affairs, Vol. 6, Num. 4 (Winter 2008): 27.

${ }^{108}$ Cf. Abdullah An-Naim, “The Synergy and Interdependence of Human Rights, Religion and Secularism," in Human Rights and Responsibilities in the World Religions, eds. Joseph Runzo, Nancy M. Martin, and Arvind Sharma (Oxford: Oneworld, 2003). Another American Muslim intellectual, An-Naim represents a far side of the spectrum in his calls for very strong secularism to protect human rights, but even he delineates his vision of secularism from a civic square devoid of religious values and expressions. 
based on religious principles. Granted, they differ on the appearance of that religious freedom. Khan holds up communal autonomy where El Fadl supports individual rights protected by the state; Sachedina likewise suggests favors individual over collective rights, with the qualification that rulers may act to preserve collective order in certain situations. Yet the substance of the right to freedom of belief is the same-a God-given dignity to every person and a divine injunction to actively respect and service that dignity. Secularists may be wary of calls for religious freedom that emanate from a "religious matrix", as Afsaruddin trenchantly notes, yet being able to make the case for pluralism and human rights in religious terms is an advantage in the context of resurgent religious sentiment and identification in Muslim-majority countries. ${ }^{109}$

Abdulaziz Sachedina, M.A. Muqtedar Khan, and Khaled Abou El Fadl represent three distinct genres within the Islamic intellectual tradition: theology, philosophy, and jurisprudence. Their scholarship—a combination of exegetical analysis and reason—follows in the long line of Muslim intellectual activity undertaken by the ulama, while their particular methodology reflects an acculturation specific to the liberal democratic context. In their work, they represent the new Muslim intellectual type who combines theoretical formulation with activism.

${ }^{109}$ Afsaruddin, 27. 


\section{CHAPTER FOUR}

\section{IMPLICATIONS AND CONCLUSION}

This paper proposed to examine and determine American Muslim rhetoric on U.S. international religious freedom policy. Their rhetoric has developed in the context of the dynamics of the international religious freedom movement, the process of their own political incorporation, and the evolution of U.S. foreign policy toward various Muslim-majority countries and communities. While slow and even hesitant to broadly support U.S. international religious freedom policy, Muslim Americans have embraced the cause of civil and religious liberty in their own domestic context, which in turn has generated new conceptual frameworks fusing Islamic principles and American values.

This theoretical fusion may help further the cause of religious freedom in the Muslimmajority world. But any potential contribution has to be weighed against three considerations: 1) the actual influence of these frameworks; 2) the domestic religious freedom context of American Muslims; and, 3) religious, political, and economic developments in the Muslim-majority world. Influence

The inevitable question that this discussion raises is one of influence. I show how Sachedina, Khan, and El Fadl have been recognized as leading intellectuals within the American Muslim community. Their activities, both theoretical and practical, have given them public platforms for their reformist agenda. But whether they, or any other Muslims from the West, are actually influential in shaping religious and political conceptions in Muslim majority countries is a separate question. General assessments by experts suggest that Muslims living on the periphery are having an impact on the "heartlands" of the Muslim world, but this remains difficult to 
quantify, and some scholars have argued that in specific cases the influence has not only declined but been reversed. ${ }^{1}$

Complicating this assessment are questions over representation and authenticity. Who really speaks for Islam? Jane McCauliffe, a noted Islamic scholar and herself a non-Muslim, points out three contemporary factors shaping this debate: the critique of Orientalism; the cooption of religious rhetoric for political purposes; and, the increasingly hybrid identities of both “insider” and "outsider.” As she asks, "How does one go about assessing and comparing the credibility an Egyptian-American raised in Michigan, an Al-Azhar educated African American Christian, or a German-born Moroccan?”2 The temptation is to quickly dismiss certain interpretations of Islamic thought and practice as unrepresentative of "true Islam,” or wild variations that sit on a fringe outside acceptable variation. Any comprehensive analysis should, however, take into account the self-perception of those articulating such concepts, and their degree of commitment to their positions. In that vein, it is both interesting and important to note that American Muslims are increasingly voicing their desire and ability to influence the wider Muslim world, even as their actual potential to affect change is debated. ${ }^{3}$

\footnotetext{
${ }^{1}$ John L. Esposito, “Faith and Practice,” in What Everyone Needs to Know About Islam, Oxford Islamic Studies Online; Osman Bakar, "The Intellectual Impact of American Muslim Scholars on the Muslim World, with Special Reference to Southeast Asia,” and Tamara Sonn, “The Declining Influence of American Muslim Scholars in Pakistan,” in Muslims in the United States: Identity, Influence, Innovation, ed. Philippa Strum (Washington, DC: Woodrow Wilson International Center for Scholars, 2005).

2 Jane Dammen McAuliffe, “Monitoring for Religious Freedom: A New International Mandate,” Religious Liberty: A Theme for Christian-Muslim Dialogue, The Commission for Religious Relations with Muslims, (Vatican City: The Pontifical Council for Inter-religious Dialogue, 2006): 157.

${ }^{3}$ Rep. Keith Ellison (MN), U.S. Congress, Hearing of the Senate Committee on Foreign Relations, “Engaging With Muslim Communities Around the World,” (February 26, 2009), http:/www.gpo.gov/fdsys/pkg/CHRG-111shrg60/pdf/CHRG-111shrg60.pdf (accessed February 26, 2009); Sherman Jackson quoted in Saban Center for Middle East Policy, New Directions: Report of the 2008 U.S.-
} 


\section{The Domestic Context}

If Muslim Americans want to serve as bridge builders to the global Muslim community, then they want to do so on their own terms. Specifically, Muslim Americans may only support international religious freedom policy if and when they feel that their own civil and religious liberties are at par with those the U.S. is trying to advance elsewhere. This reservation has an ethical and a material component. Ethically, Muslims Americans may perceive U.S. religious freedom policy abroad as hypocritical when their community continues to struggle against real and perceived discrimination at home. A precedent exists in the widespread criticism by Muslim Americans’ of the last administration’s “democracy-promotion” agenda in the Middle East even as it created and expanded domestic security measures perceived by many as constitutionally suspect. ${ }^{4}$ Moreover, continuing fractious relations with more conservative Jewish and evangelical communities — the core constituency of the religious freedom campaign—may check many American Muslims from giving anything more than a qualified public endorsement to U.S. religious freedom policy, much less actively partnering with the U.S. government.

Materially, at this stage in their political-institutional development, Muslim Americans may not have the resources to both address domestic discrimination and pursue a robust international agenda. American Muslim groups are still struggling to secure financial support,

Islamic World Forum (Washington, DC: Brookings Institution, 2008); Farah Pandith, "Outreach to Muslim Audiences," panel discussion at Center for Strategic and International Studies (November 24, 2008). For skepticism of Muslim American influence, cf. Geneieve Abdo, “Outreach to Muslim Audiences," Center for Strategic and International Studies (November 24, 2008), and "Analyzing Obama's Speech to the Muslim World," panel discussion at the Center for the Study of Islam and Democracy (June 4, 2009), https://www.csidonline.org/publications/articles/99-articles/526-analyzing-obamas-speech-to-the-muslimworld (accessed June 4, 2009).

${ }^{4}$ Erzen Ocncel, “U.S. Foreign Policy in the Middle East,” in Encyclopedia of Islam in the United States, ed. Jocelyne Cesari (Westport, CT: Greenwood Press, 2007), 414-421. 
build grassroots networks, and overcome sectarian and ethnic divisions, as well as those between immigrant and indigenous Muslims. With limited resources—financial, human, political— American Muslims are far more likely to divert attention to domestic concerns that impact them immediately rather than international policy, especially if they continue to perceive a strong sense of exclusion.

Yasmina Sameena argues in her recent study of Muslims in Australia that such perceptions, whether reflective or reality or not, can have adverse affects on political incorporation. Ideally they can be addressed at both the symbolic and practical levels, as local, state and federal governments commit to using “a new language of communal harmony,” and supporting goal-oriented interaction” between Muslims and non-Muslims. ${ }^{5}$ This theory applies across the Pacific as well: how robustly American Muslims support religious freedom policy may depend on how robustly the U.S. government takes visible and effective steps to addressing both the reality and the perception of social anxiety, discrimination, or exclusion.

Developments in the Muslim World

The treatment of Muslim minorities has become an issue for governments around the world. The Pew 2010 report “Mapping the Global Muslim Population” estimates that one-fifth— 300 million—of the worldwide Muslim population lives in non-Muslim majority countries. ${ }^{6}$ For example, China has more Muslims than Syria, and Russia more than Libya and Jordan

\footnotetext{
${ }^{5}$ Yasmin Sameena, Understanding Muslim Identities: From Perceived Relative Exclusion to Inclusion, Centre for Muslim States and Societies, University of Western Australia, May 2008, http://www.cmss.uwa.edu.au/welcome/whats_new/understanding_muslim_identities (accessed March 1, 2009).

${ }^{6}$ Pew Forum on Religion and Public Life, Mapping the Global Muslim Population (Washington, DC: Pew Research Center, 2009).
} 
combined. ${ }^{7}$ Whether in the U.S. or elsewhere, Muslims living as minorities—and not ruling—is a new phenomenon in Islamic history, and an important part of the international context of religious freedom. These communities face the double challenge of meaningfully incorporating incorporation into their host nations, and developing the religious frameworks for living in a nonMuslim culture.

As Chapter Two demonstrates, political incorporation has not always been easy even in the United States, and Muslim immigrants in Europe have arguably faced greater challenges and achieved a lesser degree of incorporation. ${ }^{8}$ The recent Swiss referendum on banning minarets, and the proposed ban on the niqab (facial veil) pending in Belgium's House of Representatives stand out as visceral examples of the fierce debate in Europe over identity, Islam and Muslims. ${ }^{9}$ Elsewhere, such as India and China, Muslim minorities must balance the strength of an older heritage and more established presence with equally well-rooted social or governmental opposition. What these communities articulate as their minority experience, and how they communicate that experience, could have the potential to reinforce or negate the American Muslim experience, at least in the short-term. Muslim minorities must also develop the religious frameworks for living as minorities. ${ }^{10}$ This is an ongoing exercise in theology and jurisprudence

\footnotetext{
${ }^{7}$ Ibid.

${ }^{8}$ Task Force on Muslim American Civic and Political Engagement, Strengthening America: The Civic and Political Integration of Muslim Americans (Chicago: Chicago Council on Global Affairs, 2007), 36.

${ }^{9}$ Nick Cumming-Bruce and Steven Erlanger, "Swiss Ban Building of Minarets on Mosques," New York Times, November 29, 2009; Raf Casert, "Parliament Panel in Belgium Approves Banning Burqa," Washington Post, March 31, 2010.

${ }^{10}$ For example, see Taha Jabir Al-Awani, Towards A Fiqh for Minorities, Occasional Papers Series 10 (London: International Institute of Islamic Thought, 2003).
} 
that will likely take considerable time, effort, and intra-Muslim cooperation. Ultimately, however, it could contribute another strand to Islamic religious freedom discourse, through analogy of Muslim minorities to non-Muslim minorities.

The evolution of non-Muslim's rights in Muslim-majority countries is likewise an evolving project. To date, declarations of religious freedom by Muslim nation-states and institutions have failed to clearly and strongly affirm freedom of religion as set forth in the 1948 United Nations Declaration of Human Rights (UNHDR). These stances are no doubt determined in part by a sensitivity to the military, economic, and cultural asymmetry between the West and the Muslim-majority world. They also reflect the fact that religious freedom discourse per se is relatively young; it was precipitated by references to ethnic minorities in national constitutions of the nineteenth century, and mentioned in the League of Nations covenant (in relation to mandate countries, e.g., Lebanon), but was first fully formulated in the UNHDR. ${ }^{11}$

Documents such as the draft Islamic constitution drawn up by Islamic scholars affiliated with Al-Azhar in 1979, the Universal Islamic Declaration of Human Rights (1981), and the Cairo Declaration of Human Rights in Islam (1990) leave the rights of religious minorities subject to Sharia, leave references to Sharia and prohibitions against “leaving Islam” out of English versions, or avoid the subject of religious minorities and religious freedom altogether: "The result

${ }^{11}$ Robert Gorman and Edward S. Mihalkanin, Historical Dictionary of Human Rights and Humanitarian Organizations, $2^{\text {nd }}$ ed., (Lanham, MD: Scarecrow Press, 2007). 
is a that comparatively innocuous text in English becomes, in the Arabic original, a minefield of ambiguity to anyone but a traditionally inclined Muslim reader.”12

The more recent Amman Message (2004) defends the freedom of conscience and belief for Muslim minorities in Muslim countries (i.e., no Muslim can call another takfir, or apostate). ${ }^{13}$ The 2008 Madrid Declaration, issued at the culmination of a global interfaith dialogue initiative sponsored by the king of Saudi Arabia, affirms the principle of equality among human beings irrespective of religion, and "respect for religions, their places of worship, and their symbols should be promoted, therefore preventing the derision of what people consider sacred,” but does not mention the freedom to proselytize. ${ }^{14}$ Finally, the successful attempt in early 2009 by Muslim nations to pass resolution in the United Nations banning “defamation of religion” met strong criticism from the European Union and the United States. ${ }^{15}$ The point here is that American Muslim discourse on religious freedom is now, and will for the near-term continue to be disparate from institutional positions formulated within the Muslim-majority world.

Three additional developments are shaping the context of the religious freedom discourse in the Muslim world: a) the crisis of religious authority; b) democratization; and, c) economic

\footnotetext{
12 Jorgen Nielsen, “Contemporary Discussions on Religious Minorities in Muslim Countries,” in Islam and Globalization: Critical Concepts in Islamic Studies, Vol. 4, ed. Shahram Akbarzadeh (Routledge: New York, 2006), 297.

13 The Royal Aal Al-Bayt Institute for Islamic Thought, The Amman Message (Amman, Jordan: The Royal Aal Al-Bayt Institute for Islamic Thought, 2008), http://www.ammanmessage.com/ (accessed September 1, 2009).

${ }^{14}$ The Madrid Declaration, World Conference on Dialogue, July 18, 2008, http://www.saudiembassy.net/print/announcement/announcement07180801.aspx (accessed April 2, 2010). 26, 2009.

${ }^{15}$ Frank Jordans, “UN Body OKs Call to Curb Religious Criticism,” Washington Times, March
} 
and educational stagnation. ${ }^{16}$ First, mass education and new communication media are eroding "hierarchical notions of religious authority based on claims to the mastery of fixed bodies of religious texts.” In turn, the public square is witnessing "increasingly open contests over the use of the symbolic language of Islam," as non-specialists make theological and religious claims independent of and often in distinction to classically trained religious authorities. ${ }^{17}$

Interestingly, if combined, the theological and juridical approaches respectively used by Sachedina and El Fadl provide a two-pronged strategy towards the crisis of religious authority. Burgeoning social science research shows that social restrictions of religious freedom drive government restrictions. ${ }^{18}$ Thus, addressing social religious intolerance is a prerequisite for longterm and sustainable reform of oppressive government controls on religion. In order effectively engage social attitudes, the best approach may be that which resonates with broad values and principles (e.g., ethics and morals). This is, in essence, the theological framework that Sachedina represents, which has promise for engaging Muslim populations from the bottom-up.

At the same time, popular religious discourse exists in tension with institutionalized Sharia. Polls show that Sharia acts as a rallying cry for Islamic identity and Islamic political theory around the world. ${ }^{19}$ It cannot simply be jettisoned as Khan indicates; nor can the

\footnotetext{
${ }^{16}$ United Nations Development Programme, Arab Human Development Report 2002 (New York: United Nations, 2002). See also the 2003 report.

${ }^{17}$ Dale Eickelman, “The Coming Transformation of the Muslim-Majority World,” in The Review of Faith and International Affairs, ed. Dennis Hoover, Vol. 7, Num. 2 (Summer 2009): 23-26.

${ }^{18}$ Brian Grim, “Is Religious Freedom Good For Us?” in “Religious Freedom and Foreign Policy,” ed. Dennis Hoover and guest editor Thomas Farr, special issue, The Review of Faith \& International Affairs Vol. 6, Num. 2 (Summer 2008): 4-5.

${ }^{19}$ Magali Rheault and Dalia Mogahed, "Iranians, Egyptians, Turks: Contrasting Views on Sharia” (July 10, 2008) and “Many Turks, Iranians, Egyptians Link Sharia and Justice,” Gallup (July 25, 2008),
} 
institutions which have grown up around the idea be conveniently displaced, i.e., the legal schools, and the place of jurists as Muslim intellectuals and holders of knowledge.

The appeal to Sharia that El Fadl makes—essentially a top-down approach—matters in terms of operationalizing religious freedom through "actual legal processes and mechanisms.”20

Second, the ebb and flow of democratization in various Muslim-majority countries has created a new space for the discussion of religious freedom as a political right. Ironically, the Bush administration's democracy-promotion agenda was undercut by its global war on terror, which provided cover for multiple governments—including “moderate” governments like Jordan— to introduce new security measures or justify existing ones and consolidate power, often at the expense of legitimate opposition. In particular, Islamic religious parties have borne much of the crackdown, which in some cases has already driven or threatens to drive them from the electoral process. $^{21}$

Many in the U.S. are now arguing that that promoting democracy in the Middle East and the broader Muslim world means engaging religious parties, with important qualifications, as we would engage other parties and democratic activists; and, qualifying support for the regimes under which they operate. ${ }^{22}$ Religious freedom can play an important role here, in terms of

available at http://www.gallup.com/poll/108724/Iranians-Egyptians-Turks-Contrasting-Views-Sharia.aspx and http://www.gallup.com/poll/109072/Many-Turks-Iranians-Egyptians-Link-Sharia-Justice.aspx. As these polls demonstrate, however, the term Sharia means different things to different people. The term can be associated broadly with justice as an ideal, rather than specific laws or institutions.

${ }^{20}$ Bernard Haykel, "Popular Support First," in Islam and the Challenge of Democracy, eds. Khaled Abou El Fadl and Joshua Cohen (Princeton, N.J.: Princeton University Press, 2004), 78-80.

${ }^{21}$ Marc Lynch “Spoilt Ballots,” The National (United Arab Emirates), November 11, 2009.

${ }^{22}$ Mona Yacoubian, Engaging Islamists and Promoting Democracy, Special Report 190 (Washington, DC: United States Institute of Peace, 2007); Saban Center for Middle East Policy, The Doha 
authenticating the public expression of religiously inspired civic values and aspirations. A recent report released by the Project on Middle East Democracy (POMED), young Arab activists explicitly expressed support for the promotion of international religious freedom by the U.S. government, linking it to the freedom of religious parties to operate in their countries' public squares. ${ }^{23}$ Given religious freedom's interdependent and multi-faceted nature, it could prove to be the best litmus test for pluralistic democracy in Muslim countries by showing that many freedoms are in place. ${ }^{24}$

As noted in Chapter Three, democracy—whether religious or political—is one of the core pegs on which American Muslim intellectuals are hanging their arguments for religious freedom. Any effort to advance religious freedom in the Muslim world must recognize the packaged aspect of religious freedom and democratic discourse. The immediate entrée point is not the protection of minority rights (as favored by the original religious freedom campaign), but the promotion of the right for majority and minority citizens to bring their religious values into the public square.

In addition to democracy, religious freedom discourse can and should be linked to economic development. The POMED report noted that respondents were concerned that economic initiatives achieve "broader social benefits," instead of enriching narrow segments of

Compact: New Directions (Washington, DC: Brookings Institution, 2008); Leadership Group on U.S.Muslim Engagement, Changing Course: A New Direction for U.S.-Muslim Relations (Washington, DC: Search for Common Ground and Consensus Building Institute, 2008); Shadi Hamid and Amanda Kadlec, Strategies for Engaging Political Islam (Washington, DC: Project on Middle East Democracy, 2010).

${ }^{23}$ Andrew Albertson, Barak Hoffman, and Tuqa Nusairat, eds., After Cairo: From the Vision of the Cairo Speech to Active Support for Human Dignity (Washington, DC: Project on Middle East Democracy, 2010): 8-10, 20, 23.

${ }^{24}$ H. Knox Thames, Chris Seiple, and Amy Rowe, International Religious Freedom Advocacy (Waco, TX: Baylor University Press, 2009), 9. 
the population. Social science research that correlates religious freedom to socio-economic progress can be helpful here, especially with the rise of the "critical middle," a term Vali Nasr uses to describe the rising entrepreneurial middle class in the Muslim world that seeks to blend economic vitality with Islamic values. ${ }^{25}$ An economically-savvy and religiously observant class would likely make an "attentive audience” to a religious freedom discourse that combined hard data with moral appeal.

\section{Conclusion}

American Muslims have produced a fusion of Islamic and American values that holds potential for the advancement of religious freedom in the Muslim world. This discourse grows out of an evolving domestic and international context, where social, political, and economic changes are creating new space for the reception—and even expectation—of greater human development. If American Muslim discourse is to complement these changes, the community must continue the process of successful political incorporation. Without full ownership of civil and religious liberty at home, Muslim Americans cannot and will not effectively advance religious freedom abroad.

Nor can they promote religious freedom if there is no sustained, meaningful religious freedom policy. As of this writing, the Obama administration has yet to name even a candidate for the position of Ambassador at Large for Religious Freedom. The recent (March 2010) letter from a group of scholars, activists, and policy thinkers, including three experienced Muslim American leaders, urging President Obama to fill the position soon illustrates the gains and

\footnotetext{
${ }^{25}$ Vali Nasr, Forces of Fortune: The Rise of the New Muslim Middle Class and What It Will Mean for Our World (New York: Free Press, 2009). This citation is taken from the excerpt available on the website of the Council on Foreign Relations, http://www.cfr.org/publication/20056/?excerpt=1 (accessed January 1, 2010).
} 
shortcomings of the religious freedom movement to date. ${ }^{26}$ A broader, more truly inter-faith consensus combined with academic analysis has strengthened the rhetorical and logical case for advancing international religious freedom—while a reticence to meaningfully execute the Congressional mandate in IRFA persists at the highest governmental levels. Ultimately, American Muslim discourse on religious freedom may prove to be effective not just at building cross-cultural bridges, but helping to build and maintain domestic support for the active governmental promotion of this most precious of human rights.

${ }^{26}$ Thomas Farr, “Undefender of the Faith,” ForeignPolicy.com, April 5, 2010, http://www.foreignpolicy.com/articles/2010/04/05/undefender_of_the_faith (accessed April 8, 2010). The letter is available at http://www.globalengage.org/pressroom/releases/1146-obama-ambassadorinternational-religious-freedom.html (accessed April 8, 2010). 


\section{BIBLIOGRAPHY}

Abdo, Geneive. “Separate But Unequal.” The Washington Quarterly, Volume 28:4 (Autumn 2005): 7-17.

Abou El Fadl, Khaled and Joshua Cohen, eds. Islam and the Challenge of Democracy. Princeton: Princeton University Press, 2004.

Abou El Fadl, Khaled and Joshua Cohen, eds. The Place of Tolerance in Islam. Boston: Beacon Press, 2002.

Abou El Fadl, Khaled. “The Human Rights Commitment in Modern Islam.” In Human Rights and Responsibilities in the World Religions, edited by Joseph Runzo, Nancy M. Martin. and Arvind Sharma, 301-364. Oxford: Oneworld, 2003.

Abou El Fadl, Khaled. “The Unique and International and the Imperative of Discourse.” Chicago Journal of International Law, Volume 8, Number 1 (2007): 43-57.

Afsaruddin, Asma. “Absolutism vs. Pluralism in Islam Today.” The Review of Faith \& International Affairs, Volume 6, Number 4 (Winter 2008): 23-28.

Al-Awani, Taha Jabir. Towards A Fiqh for Minorities. International Institute of Islamic Thought Occasional Papers Series 10. London: IIIT, 2003.

Albertson, Andrew, Barak Hoffman and Tuqa Nusairat, editors. After Cairo: From the Vision of the Cairo Speech to Active Support for Human Dignity. Washington, DC: Project on Middle East Democracy, 2010.

An-Naim, Abdullah. "The Synergy and Interdependence of Human Rights, Religion and Secularism.” In Human Rights and Responsibilities in the World Religions, edited by Joseph Runzo, Nancy M. Martin, and Arvind Sharma, 27-50. Oxford: Oneworld, 2003.

Bakar, Osman. "The Intellectual Impact of American Muslim Scholars on the Muslim World, with Special Reference to Southeast Asia," and "Competing Visions of Islam in Southeast Asia: American Muslim Scholarship as a Shaping Factor.” In Strum, 87-102, and 103-120.

Barrett, Paul. American Islam: The Struggle for the Soul of a Religion. New York: Picador, 2008.

Berkley Center for Religion. Peace \& World Affairs. Report of the Georgetown Symposia on U.S. International Religious Freedom Policy. Washington. DC: Georgetown University, 2008. 
Cesari, Jocelyne, ed. Encyclopedia of Islam in the United States. Volumes 1-2. Westport, CT: Greenwood Press, 2007.

Cimino, Richard. "No God in Common: American Evangelical Discourse on Islam After 9/11." Review of Religious Research, Volume 47, Number 2 (2005): 162-174.

Curtis, Edward E. IV. Islam in Black America. Albany, NY: State University Press of New York, 2002.

Davis, Winston, ed. Taking Responsibility: Comparative Perspectives. Charlottesville: University Press of Virginia, 2001.

Eickelman, Dale. “The Coming Transformation of the Muslim-Majority World.” The Review of Faith and International Affairs, Volume 7, Number 2 (Summer 2009): 23-26.

Esposito, John L., ed. The Oxford Dictionary of Islam, Oxford Islamic Studies Online. http://www.oxfordislamicstudies.com/Public/Home.html?url=/app\%3Fservice\%3Dextern alpagemethod\%26method\%3Dview\%26page\%3DHome\&failReason= (accessed August 1, 2009).

Esposito, John L. and John Voll. Makers of Contemporary Islam. New York: Oxford University Press, 2001.

Fadel, Mohammad. “Too Far From Tradition.” In Abou El Fadl and Cohen, Islam and the Challenge of Democracy, 81-86.

Farr, Thomas and Dennis R. Hoover. The Future of U.S. International Religious Freedom Policy: Recommendations for the Obama Administration. Washington, DC: Georgetown University and The Institute for Global Engagement, 2009.

Farr, Thomas. World of Faith and Freedom. New York: OUP, 2008.

Gallup. Muslim Americans: A National Portrait. Washington, DC: Gallup, 2009.

Gerstle, Gary. “The Political Incorporation of Immigrant Groups.” In American Arabs and Political Participation, edited by Philippa Strum, 27-40. Washington, DC: Woodrow Wilson International Center for Scholars, 2004.

Gorman, Robert and Edward S. Mihalkanin. Historical Dictionary of Human Rights and Humanitarian Organizations. $2^{\text {nd }}$ edition. Lanham, MD: Scarecrow Press, 2007.

Gottschalk, Peter and Gabriel Greenberg. Islamophobia: Making Muslims the Enemy. New York: Rowman \& Littlefield, 2008. 
Grim, Brian. "Is Religious Freedom Good for Us?” In "Religious Freedom and Foreign Policy,” ed. Dennis Hoover and guest editor Thomas Farr. Special issue, The Review of Faith \& International Affairs, Volume 6, Number 2 (Summer 2008): 3-8.

Gunn, T. Jeremy. “A Preliminary Response to Criticisms of the International Religious Freedom Act of 1998.” Brigham Young University Law Review, Volume 3 (2000): 841-865.

Gutmann, Amy. “Religious Freedom and Civic Responsibility.” In Davis, 47-62.

Haddad, Yvonne, ed. Muslims in the West: From Sojourners to Citizens. New York: OUP, 2002.

Haddad, Yvonne, ed. The Muslims of America. New York: OUP, 1991.

Haines, Byron. "Perspectives of the American Churches on Islam and the Muslim Community in North America.” In Haddad, The Muslims of America, 39-52.

Hamid, Shadi and Amanda Kadlec. Strategies for Engaging Political Islam. Washington, DC: Project on Middle East Democracy, 2010.

Hanford, Laura Bryant. "The International Religious Freedom Act: Sources, Policy, Influence.” In "Religious Freedom and Foreign Policy," ed. Dennis Hoover and guest editor Thomas Farr. Special issue, The Review of Faith \& International Affairs Volume 6, Number 2 (Summer 2008): 33-40.

Hasan, Asma Gul. American Muslims: The New Generation. 2nd edition. New York: Continuum, 2002.

Hashemi, Nader. "Inching Towards Democracy: Religion and Politics in the Muslim World.” Third World Quarterly, Volume 24, Number 3 (2003): 573-574.

Haykel, Bernard. "Popular Support First.” In Abou El Fadl and Cohen, Islam and the Challenge of Democracy, 78-80.

Hertzke, Allen. Freeing God's Children: The Unlikely Alliance for Global Human Rights. Lanham, MD: Rowman \& Littlefield, 2004.

Hertzke, Allen. "International Religious Freedom Policy: Taking Stock.” In "Religious Freedom and Foreign Policy,” ed. Dennis Hoover and guest editor Thomas Farr. Special issue, The Review of Faith \& International Affairs Volume 6, Number 2 (Summer 2008): 17-24.

Inboden, William. “ Presidential Promotion of International Religious Freedom.” In "Religious 
Freedom and Foreign Policy,” ed. Dennis Hoover and guest editor Thomas Farr. Special issue, The Review of Faith \& International Affairs Volume 6, Number 2 (Summer 2008): 41-45.

Jackson, Sherman A. Islam and the Blackamerican: Looking Toward the Third Resurrection. New York: OUP, 2005.

Jackson, Sherman. "Black Orientalism: Its Genesis, Aims and Significance for American Islam.” In Strum, 37-50.

Kamrava, Mehran. The New Voices of Islam: Rethinking Politics and Modernity. Berkeley: University of California Press, 2006.

Khan, M.A. Muqtedar. “The Politics. Theory. and Philosophy of Islamic Democracy.” In Islamic Democratic Discourse: Theory, Debates, and Philosophical Perspectives, edited by M.A. Muqtedar Khan, 149-171. Lanham, MD: Lexington Books, 2006.

Khan, M.A. Muqtedar. “The Primacy of Political Philosophy.” In Islam and the Challenge of Democracy, edited by Joshua Cohen, Deborah Chasman and Khalid Abou El Fadl, 6368. Princeton: Princeton University Press, 2004.

Khan, M.A. Muqtedar. American Muslims: Bridging Faith and Freedom. Beltsville, MD: Amana Publications, 2002.

Kidd, Thomas. "Islam in American Protestant Thought.” Books \& Culture: A Christian Review, Volume 12, Number 5 (September/October 2006): 39-41.

Leonard, Karen. "South Asian Leadership of American Muslims.” In Haddad, Muslims in the West, 233-249.

Lindsay, D. Michael. Faith in the Halls of Power. New York: Oxford University Press, 2007.

McAuliffe, Jane Dammen. "Monitoring for Religious Freedom: A New International Mandate.” In Religious Liberty: A Theme for Christian-Muslim Dialogue. The Commission for Religious Relations with Muslims. Vatican City: The Pontifical Council for Interreligious Dialogue, 2006.

Mubarak, Hadia. "How Muslim Students Negotiate Their Religious Identity and Practices in an Undergraduate Setting.” Social Science Research Council, May 8, 2007.

Muslim West Facts Project. Religious Perceptions in America. Washington, DC: Gallup and The Coexist Foundation, 2009. 
Nasr, Vali. Forces of Fortune: The Rise of the New Muslim Middle Class and What It Will Mean for Our World. New York: Free Press, 2009.

Nielsen, Jorgen. “Contemporary Discussions on Religious Minorities in Muslim Countries.” In Islam and Globalization: Critical Concepts in Islamic Studies, edited by Shahram Akbarzadeh, Volume 4. Routledge: New York, 2006.

Nimer, Mohammed. “American Muslim Organizations: Before and After 9/11.” In Strum, 5-18.

Nimer, Mohammed. "Muslims in American Public Life.” In Haddad, Muslims in the West, 169-186.

Noll, Mark A. The New Shape of World Christianity. Downers Grove. IL: Intervarsity Press, 2009.

Nyang, Sulayman. Islam in the United States of America. Chicago: ABC International Group, 1999.

Pew Forum on Religion and Public Life. Mapping the Global Muslim Population. Washington, DC: Pew Research Center, 2009.

Pew Research Center. Muslim Americans: Middle Class and Mostly Mainstream Washington, DC: Pew Research Center, 2007.

Philpott, Daniel. "In Search of the Twin Tolerations.” In "Religious Freedom and Foreign Policy," ed. Dennis Hoover and guest editor Thomas Farr. Special issue, The Review of Faith \& International Affairs, Volume 6, Number 2 (Summer 2008): 9-12.

Pipes, Daniel. “Are Muslim Americans Victimized?”. Commentary, Volume 110, Iss. 4 (November 2008): 33-37. http://0-www.proquest.com.library.lausys.georgetown.edu (accessed March 15, 2010).

Rauf, Feisal Abdul. What's Right with Islam: A New Vision for Muslims and the West.1st edition. San Francisco: Harper, 2004.

Saban Center for Middle East Policy. New Directions: Report of the 2008 U.S.-Islamic World Forum. Washington, DC: Brookings Institution, 2008.

Saban Center for Middle East Policy. The Doha Compact: New Direction.s Washington, DC: Brookings Institution, 2008. 
Sachedina, Abdulaziz. “Jews, Christians, and Muslims According to the Qur'an.” Greek Orthodox Theological Review, Volume 31, Number 1 (1986):105-120. http://0search.ebscohost.com.library.lausys.georgetown.edu/login.aspx?direct $=$ true \&db=rfh\&A

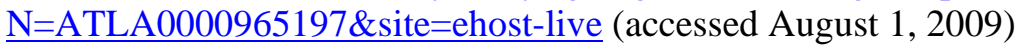

Sachedina, Abdulaziz. “The Role of Islam in the Public Square: Guidance or Governance?” In Islamic Democratic Discourse: Theory. Debates. and Philosophical Perspectives, edited by M.A. Muqtedar Khan, 173-192. Lanham, MD: Lexington Books, 2006.

Sachedina, Abdulaziz. The Islamic Roots of Democratic Pluralism. New York: Oxford University Press, 2001.

Sachedina, Abdulaziz. "Civic Responsibility in Political Society: An Islamic Paradigm.” In Taking Responsibility: Comparative Perspectives, edited by Winston Davis, 231-252. Charlottesville, VA: University Press of Virginia, 2001.

Sameena, Yasmin. Understanding Muslim Identities: From Perceived Relative Exclusion to Inclusion. University of Western Australia, Centre for Muslim States and Societies, 2008.

Shea, Nina. "The Origins and Legacy of the Movement to Fight Religious Persecution.” In "Religious Freedom and Foreign Policy," ed. Dennis Hoover and guest editor Thomas Farr. Special issue, The Review of Faith \& International Affairs, Volume 6, Number 2 (Summer 2008): 25-32.

Simon, Yves. A General Theory of Authority. Notre Dame: University of Notre Dame Press, 1980.

Skreslet, Paula and Rebecca Skreslet. The Literature of Islam: A Guide to the Primary Sources. Lanham, MD: Scarecrow Press, 2006.

Smock, David and Qamar ul-Huda. Islamic Peacemaking Since 9/11. United States Institute of Peace Special Report Number 218. Washington. DC: USIP, 2009.

Smock, David. Ijtihad: Reinterpreting Islamic Principles for the Twenty-first Century. United States Institute of Peace Special Report 125 Washington. DC: USIP. 2004.

Sonn, Tamara. “The Declining Influence of American Muslim Scholars in Pakistan.” In Strum, 121-130.

Stahnke, Tad. "A Paradox of Independence: The U.S. Commission on International Religious Freedom.” In "Religious Freedom and Foreign Policy,” ed. Dennis Hoover and guest editor Thomas Farr. Special issue, The Review of Faith \& International Affairs Volume 6, Number 2 (Summer 2008): 47-51. 
Strum, Philippa, ed. Muslims in the United States: Identity, Influence, Innovation. Washington, DC: Woodrow Wilson International Center for Scholars, 2005.

Surush, Abd al-Karim. Mahmoud Sadri and Ahmad Sadri. Reason. Freedom. \& Democracy in Islam: Essential Writings of 'Abdolkarim Soroush. New York: Oxford University Press, 2000 .

Task Force on Muslim American Civic and Political Engagement. Strengthening America: The Civic and Political Integration of Muslim Americans. Chicago: Chicago Council on Global Affairs, 2007.

Thames, H. Knox, Chris Seiple, and Amy Rowe. International Religious Freedom Advocacy. Waco, TX: Baylor University Press, 2009.

The Leadership Group on U.S.-Muslim Engagement. Changing Course: A New Direction for U.S.-Muslim Relations. Washington, DC: Search for Common Ground and The Consensus Building Institute, 2008.

U.S. Department of State Bureau of International Information Programs. Being Muslim in America. Washington, DC: Government Printing Office, 2009.

United Nations Development Programme. Arab Human Development Report 2002. New York: United Nations, 2002.

Yacoubian, Mona. Engaging Islamists and Promoting Democracy. United States Institute of Peace Special Report 190. Washington, DC: United States Institute of Peace, 2007. 